\title{
Essential Roles of Enteric Neuronal Serotonin in Gastrointestinal Motility and the Development/Survival of Enteric Dopaminergic Neurons
}

\author{
Zhishan Li, ${ }^{1}$ Alcmène Chalazonitis, ${ }^{1}$ Yung-yu Huang, ${ }^{2}$ J. John Mann, ${ }^{2}$ Kara Gross Margolis, ${ }^{3}$ Qi Melissa Yang, ${ }^{4}$ \\ Dolly 0. Kim, ${ }^{1}$ Francine Côté, ${ }^{5}$ Jacques Mallet, ${ }^{6}$ and Michael D. Gershon ${ }^{1}$ \\ Departments of ${ }^{1}$ Pathology and Cell Biology, ${ }^{2}$ Psychiatry, and ${ }^{3}$ Pediatrics, Columbia University, New York, New York 10032, ${ }^{4}$ Lexicon Pharmaceuticals, The \\ Woodlands, Texas 773814, ${ }^{5}$ Centre National de la Recherche Scientifique (CNRS), Unité Mixte de Recherche (UMR) 8147, Hôpital Necker, 70015 Paris, \\ France, and ${ }^{6} \mathrm{CNRS}$, UMR 7225, Hôpital de la Pitié-Salpêtrière, 75013 Paris, France
}

The gut contains a large 5-HT pool in enterochromaffin (EC) cells and a smaller 5-HT pool in the enteric nervous system (ENS). During development, enteric neurons are generated asynchronously. We tested hypotheses that serotonergic neurons, which arise early, affect development/survival of later-born dopaminergic, GABAergic, nitrergic, and calcitonin gene-related peptide-expressing neurons and are essential for gastrointestinal motility. 5-HT biosynthesis depends on tryptophan hydroxylase 1 (TPH1) in EC cells and on TPH2 in neurons; therefore, mice lacking TPH1 and/or TPH2 distinguish EC-derived from neuronal 5-HT. Deletion of TPH2, but not TPH1, decreased myenteric neuronal density and proportions of dopaminergic and GABAergic neurons but did not affect the extrinsic sympathetic innervation of the gut; intestinal transit slowed in mice lacking TPH2 mice, but gastric emptying accelerated. Isolated enteric crest-derived cells (ENCDCs) expressed the serotonin reuptake transporter (SERT) and 15 subtypes of 5-HT receptor. Addition of 5-HT to cultures of isolated ENCDCs promoted total and dopaminergic neuronal development. Rings of SERT-immunoreactive terminal axons surrounded myenteric dopaminergic neurons and SERT knock-out increased intestinal levels of dopamine metabolites, implying that enteric dopaminergic neurons receive a serotonergic innervation. Observations suggest that constitutive gastrointestinal motility depends more on neuronal than EC cell serotonin; moreover, serotonergic neurons promote development/survival of some classes of late-born enteric neurons, including dopaminergic neurons, which appear to innervate and activate in the adult ENS.

\section{Introduction}

The enteric nervous system (ENS) mediates gastrointestinal (GI) behavior independently of CNS input (Furness, 2006; Gershon and Tack, 2007). This ability is reflected in ENS complexity, neuronal phenotypic diversity, and intrinsic microcircuits. Transepithelial signaling, involving pressure- or nutrientinduced secretion of paracrine messengers, such as serotonin (5HT) from enterochromaffin (EC) cells, initiates motor and secretory reflexes (Bülbring and Crema, 1959a; Cooke et al., 1997; Pan and Gershon, 2000; Bertrand, 2004; Patel et al., 2007; Spiller, 2007). Although EC cells contain most of the 5-HT of the bowel, 5-HT is also a neurotransmitter of descending myenteric interneurons (Monro et al., 2002; Gershon and Tack, 2007; Gershon, 2009; Neal et al., 2009).

Tryptophan hydroxylase (TPH) is the rate-limiting enzyme in 5-HT biosynthesis (Noguchi et al., 1973). Two different genes

Received Dec. 21, 2010; revised April 22, 2011; accepted April 26, 2011.

Author contributions: M.D.G. designed research; Z.L., A.C., Y.-y.H., K.G.M., D.O.K., F.C., and J.M. performed research;Z.L., A.C., Y.-y.H., J.J.M., K.G.M., Q.M.Y., D.O.K., F.C., J.M., and M.D.G. analyzed data; Z.L. and M.D.G. wrote the paper.

This work was supported by NIH Grants NS15547 and NS12969.

Correspondence should be addressed to Zhishan Li, Department of Pathology and Cell Biology, Columbia University, College of Physicians and Surgeons, 630 West 168th Street, New York, NY 10032. E-mail: zl64@columbia.edu. DOI:10.1523/JNEUROSCI.6684-10.2011

Copyright $\odot 2011$ the authors $\quad 0270-6474 / 11 / 318998-12 \$ 15.00 / 0$ encode TPH isoforms: TPH1 is found in EC and mast cells (Côté et al., 2003; Chen et al., 2004; Ghia et al., 2009), and TPH2 is found in enteric neurons (Chen et al., 2004; Neal et al., 2009) and brain (Walther et al., 2003; Gutknecht et al., 2009). TPH1 ablation (TPH1KO) depletes mucosal but not neuronal 5-HT (Walther et al., 2003), whereas TPH2 ablation (TPH2KO) depletes 5-HT from neurons (Gutknecht et al., 2009) but, because EC cells contain so much more 5-HT than neurons, hardly changes total gut 5-HT. TPH1KO and TPH2KO mice thus distinguish effects of mucosal from neuronal 5-HT. Uptake, mediated primarily by the serotonin transporter (SERT), terminates the action of released 5-HT. Enterocytes and serotonergic neurons express SERT (Wade et al., 1996; Chen et al., 1998). SERT ablation enhances 5-HT effects (Coates et al., 2006; Bian et al., 2007; Patel et al., 2007; Bertrand et al., 2008; Bertrand and Bertrand, 2010). Actions of endogenous 5-HT can thus be studied with gain-of-function experiments in mice lacking SERT (SERTKO).

The ENS is derived from émigrés from the neural crest (Yntema and Hammond, 1954, 1955; Le Douarin and Teillet, 1973; Gershon and Ratcliffe, 2006). Enteric neurons of different phenotypes are born at different ages (Pham et al., 1991); therefore, early-born neurons as well as growth factors in the enteric microenvironment (Hao and Young, 2009; Laranjeira and Pachnis, 2009) might influence the differentiation of uncommitted enteric 
crest-derived cells (ENCDCs). Enteric serotonergic neurons (embryonic days E8.5-E15) are among the first to be born, and dopaminergic (perinatal), calcitonin gene-related peptide (CGRP)-expressing, GABAergic, and some nitrergic neurons are among the last to be born (Pham et al., 1991; Blaugrund et al., 1996; Li et al., 2004; Chalazonitis et al., 2008). Because serotonergic neurons thus coexist with precursor cells, they have the potential to affect neuronal development/survival of dopaminergic and other late-born enteric neurons.

We tested hypotheses that development/survival of late-born enteric neurons and gastrointestinal motility are dependent on enteric neuronal 5-HT. Loss of function was studied in mice lacking TPH1 and/or TPH2; gain of function was investigated in SERTKO mice and in cultures of isolated ENCDCs treated with 5-HT. Observations suggest that constitutive gastrointestinal motility depends more on neuronal than on mucosal 5-HT and that the development of dopaminergic, GABAergic, and CGRPexpressing enteric neurons requires neuronal 5-HT.

\section{Materials and Methods}

Animals and tissue preparation. Experiments were performed with adult TPH1KO (Hôpital de la Pitié-Salpètrière, Paris, France), TPH2KO (provided by Gérard Karsenty, Columbia University, New York, NY and by Lexicon Pharmaceuticals), TPH1 and TPH2 double KO (Savelieva et al., 2008) (TPH1/2dKO; Lexicon Pharmaceuticals), and SERTKO (Taconic Farms) mice. Wild-type (WT) littermates of these animals were used as controls (129S5/SvEvBrd and C57BL/6J hybrid background for Lexicon Pharmaceuticals mice; C57BL/6 for the rest). CD-1 mice were used for in vitro studies of E16 fetal bowel and to investigate whether or not enteric dopaminergic neurons of WT mice express SERT immunoreactivity. Tyrosine hydroxylase $(\mathrm{TH})$-immunoreactive neurons are more far more abundant in CD-1 than in C57BL/6 or $129 \mathrm{~S} 5 / \mathrm{SvEvBrd}$ and C57BL/6J hybrid animals. Mice of either sex were used. The day at which a vaginal plug was found was designated as day 0 of gestation. $\mathrm{CO}_{2}$ inhalation was used to kill adult animals. The Animal Care and Use Committee of Columbia University approved this procedure.

$R N A$ extraction and preparation of $c D N A$. Tissues and immunoisolated ENCDCs (see below) were collected and cleaned with PBS, pH 7.4, which had been treated with $0.1 \%$ diethyl pyrocarbonate. RNA was isolated with Trizol (Invitrogen) according to the instructions of the manufacturer. RNA was then treated with DNase I $(1 \mathrm{U} / \mathrm{ml})$ to prevent genomic DNA contamination. Maloney murine leukemia virus reverse transcriptase (Promega) was used to prepare cDNA.

$R T-P C R$. cDNA, prepared from immunoisolated ENCDCs (see below) and brain, which was investigated as a positive control, was subjected to PCR analysis to determine whether ENCDCs express transcripts encoding subtypes of 5-HT receptors, SERT, and p75 ${ }^{\text {NTR }}$ (Table 1). Reverse transcriptase was omitted from duplicate preparations before PCR analysis to provide a negative control against the possibility of genomic contamination. Subtypes of 5 -HT receptor investigated included $5-\mathrm{HT}_{1 \mathrm{~A}}, 5-\mathrm{HT}_{1 \mathrm{~B}}, 15-\mathrm{HT}_{1 \mathrm{D}}, 5-\mathrm{HT}_{1 \mathrm{~F}}, 5-\mathrm{HT}_{2 \mathrm{~A}}, 5-\mathrm{HT}_{2 \mathrm{~B}}, 5-\mathrm{HT}_{3 \mathrm{~A}}$, $5-\mathrm{HT}_{4 \mathrm{~A}}, 5-\mathrm{HT}_{4 \mathrm{~B}}, 5-\mathrm{HT}_{4 \mathrm{E}}, 5-\mathrm{HT}_{4 \mathrm{~F}}, 5-\mathrm{HT}_{5 \mathrm{~A}}, 5-\mathrm{HT}_{5 \mathrm{~B}}, 5-\mathrm{HT}_{6}$, and $5-\mathrm{HT}_{7}$ receptors. The $5-\mathrm{HT}_{2 \mathrm{C}}$ receptor was not investigated because it has been shown previously not to be expressed in the fetal bowel (Fiorica-Howells et al., 2000), and $5-\mathrm{HT}_{3 \mathrm{~B}}$ was not studied because it is incapable of mediated responses in the absence of $5-\mathrm{HT}_{3 \mathrm{~A}}$ receptors (Davies et al., 1999), which are expressed in the adult gut (Liu et al., 2002) and were investigated.

Real-time PCR. Real-time RT-PCR was used to quantify transcripts encoding dopamine transporter (DAT), SERT, and TH. A 7500 Fast Real-Time PCR System (Applied Biosystems) was used for this purpose. The $20 \mu \mathrm{l}$ PCR reaction solution contained $10 \mu \mathrm{l}$ of $2 \times$ TaqMan Fast Universal PCR Master Mix (Applied Biosystems), $2 \mu$ of cDNA (10-100 ng), $1 \mu \mathrm{l}$ of primers and probes (18 $\mu \mathrm{M}$ forward primer, $18 \mu \mathrm{M}$ reverse primer and $5 \mu \mathrm{M}$ TaqMan probe; Applied Biosystems), and $7 \mu \mathrm{l}$ of RNase-free $\mathrm{H}_{2} \mathrm{O}$. Conditions were as follows: $95^{\circ} \mathrm{C}$ for $20 \mathrm{~s} ; 40$ cycles of $95^{\circ} \mathrm{C}$ for $3 \mathrm{~s}$; and $60^{\circ} \mathrm{C}$ for $30 \mathrm{~s}$. The threshold cycle was calculated by the
Table 1. Sequences of primers

\begin{tabular}{|c|c|c|c|c|}
\hline Primers & $\begin{array}{l}\text { Accession } \\
\text { number }\end{array}$ & Sequences $\left(5^{\prime}-3^{\prime}\right)$ & Primer location & $\begin{array}{l}\text { Annealing } \\
\text { temp }\left({ }^{\circ} \mathrm{C}\right)\end{array}$ \\
\hline \multirow[t]{2}{*}{$5-\mathrm{HT}_{1 \mathrm{~A}}$} & \multirow[t]{2}{*}{ NM_008308 } & F, ccecccaagaagagectgaa & $1236-1255$ & \multirow[t]{2}{*}{58} \\
\hline & & R, ggcagccagcagaggatgaa & $1570-1551$ & \\
\hline \multirow[t]{2}{*}{$5-\mathrm{HT}_{1 \mathrm{~B}}$} & \multirow[t]{2}{*}{ NM_010482 } & $\mathrm{F}, \mathrm{tccgggtctcctgtgtacgt}$ & $829-848$ & \multirow[t]{2}{*}{58} \\
\hline & & $\mathrm{R}$, ggcgtctgagactcgcactt & $879-860$ & \\
\hline \multirow{2}{*}{$5-\mathrm{HT}_{1 \mathrm{D}}$} & \multirow[t]{2}{*}{ NM_008309 } & $\mathrm{F}$, ggctccectctctttttcaac & $1767-1787$ & \multirow[t]{2}{*}{58} \\
\hline & & R, gcagagatcctcttgcgttc & $1840-1821$ & \\
\hline \multirow[t]{2}{*}{$5-\mathrm{HT}_{1 \mathrm{~F}}$} & \multirow[t]{2}{*}{ NM_008310 } & $\mathrm{F}$, tacagagcagcaaggacac & $923-941$ & \multirow[t]{2}{*}{60} \\
\hline & & R, acaaaaaagggcagccaac & $1242-1224$ & \\
\hline \multirow[t]{2}{*}{$5-\mathrm{HT}_{2 \mathrm{~A}}$} & \multirow[t]{2}{*}{ NM_172812 } & $\mathrm{F}$, agaagccaccttgtgtgtga & 1882-1901 & \multirow[t]{2}{*}{58} \\
\hline & & $R$, ttgctcattgctgatggact & $2050-2031$ & \\
\hline \multirow{2}{*}{$5-\mathrm{HT}_{2 \mathrm{~B}}$} & \multirow[t]{2}{*}{ NM_008311 } & $\mathrm{F}$, atagccatcaaaaagccaa & $787-805$ & \multirow[t]{2}{*}{58} \\
\hline & & R, tgttaggcgttgaggtgg & $1104-1087$ & \\
\hline \multirow[t]{2}{*}{$5-\mathrm{HT}_{3 \mathrm{~A}}$} & \multirow[t]{2}{*}{ NM_013561 } & F, gccacccaggaggataccac & $142-162$ & \multirow[t]{2}{*}{58} \\
\hline & & $R$, gctcccactcgecctgattt & $703-684$ & \\
\hline \multirow[t]{2}{*}{$5-\mathrm{HT}_{4 \mathrm{~A}}$} & \multirow[t]{2}{*}{ Y09587 } & F, ccaaggcagccaagacttta & $766-785$ & \multirow[t]{2}{*}{58} \\
\hline & & R, gcaaaactgtataccttagtacatgggtg & 1092-1061 & \\
\hline \multirow[t]{2}{*}{$5-\mathrm{HT}_{4 \mathrm{~B}}$} & \multirow[t]{2}{*}{ Y09585 } & F, ccaaggcagccaagacttta & $766-785$ & \multirow[t]{2}{*}{58} \\
\hline & & $R$, agcagccaccaaaggagaag & $1151-1132$ & \\
\hline \multirow[t]{2}{*}{$5-\mathrm{HT}_{4 \mathrm{E}}$} & \multirow[t]{2}{*}{ Y09588 } & F, ccaaggcagccaagacttta & $766-785$ & 58 \\
\hline & & R:ggtctattgcggaagagcagggggaaactt & $1105-1076$ & \\
\hline $5-\mathrm{HT}_{4 \mathrm{~F}}$ & AJ011369 & F, ccaaggcagccaagacttta & $766-785$ & 58 \\
\hline & & R, gttagacgggaacaggtcttagtacatg & 1095-1068 & \\
\hline $5-\mathrm{HT}_{5 \mathrm{~A}}$ & NM_008314 & $\mathrm{F}$, cctccttttctctctctact & $525-544$ & 58 \\
\hline & & $\mathrm{R}$, aaagtcaggactagcactcg & $639-620$ & \\
\hline $5-\mathrm{HT}_{5 \mathrm{~B}}$ & NM_010483 & F, cccettgatttacactgce & $1317-1335$ & 58 \\
\hline & & $R$, cagaaatggagcacaattcac & $1627-1607$ & \\
\hline $5-\mathrm{HT}_{6}$ & NM_021358 & $\mathrm{F}$, ttccagagccaggecctgtc & $33-52$ & 60 \\
\hline & & R, tagcggtccaggctgatga & $402-384$ & \\
\hline $5-\mathrm{HT}_{7}$ & NM_008315 & $\mathrm{F}$, ttcgagactgctcaaacac & $1031-1049$ & 54 \\
\hline & & $R$, tgcagcagagagcttccggt & $1356-1336$ & \\
\hline $\mathrm{p} 75^{\mathrm{NTR}}$ & NM_033217 & $\mathrm{F}$, ccgatacggtgaccactgtgatg & $835-857$ & 58 \\
\hline & & R, agcagccaagatggagcaatagac & 932-909 & \\
\hline SERT & Y08870 & F, caaaaccaagaaccaagag & $98-116$ & 57 \\
\hline & & $R$, catagccaatgacagacag & $454-436$ & \\
\hline
\end{tabular}

F, Forward; R, reverse. Accession numbers are from GenBank.

software of the instrument (7500 Fast System version 1.3.1). Data were analyzed with computer assistance by using the 7500 Software for 7500 Fast Real Time PCR (version 2.0.4; Applied Biosystems). For each sample, the expression of DAT, SERT, or TH was normalized to glyceraldehyde-3-phosphate dehydrogenase (GAPDH). All primers and probes were purchased from Applied Biosystems (DAT, catalog \#Mm00438388; GAPDH, catalog \#4352339E; SERT, catalog \#Mm00439391_m1; TH, catalog \#Mm00447557).

Measurement of DA, 3-methoxy 4-hydroxyvanillic acid, 5-HT, and 5-hydroxyindoleacetic acid. Gut, brain (examined as a positive control), and cultured cells were ultrasonically disrupted in $\sim 10$ vol of $0.4 \mathrm{M}$ perchloric acid. Homogenates were centrifuged for $5 \min (14,000 \times g$; $\left.4^{\circ} \mathrm{C}\right)$. The supernatant was removed and centrifuged again in a new tube. An aliquot $(20-50 \mu \mathrm{l})$ of the supernatant was subjected to HPLC. The HPLC system consisted of a Waters 515 pump, a Waters 717 Autosampler with cooling system, a Varian Dynamax C-18 reverse-phase column (Microsorb 100-5 C18, $150 \times 4.6 \mathrm{~mm}$ ), and a Dynamax HPLC Guard Column $(4.8 \mathrm{~mm})$. An electrochemical detector was used (model 5100A with a guard cell and model 5011 with a dual analytical cell; ESA Coulochem). The electrochemical detector was set at a potential of $+0.04 \mathrm{~V}$ for the first cell and at $+0.5 \mathrm{~V}$ for the second cell. The mobile phase buffer contained $0.75 \mathrm{~mm}$ sodium monophosphate, $\mathrm{pH} 3.1,1.4 \mathrm{~mm}$ 1-octanesulfonic acid, $0.01 \mathrm{~mm}$ disodium EDTA, and 7\% acetonitrile. The mobile phase buffer was filtered through a membrane with a 0.22 $\mu \mathrm{m}$ pore (Type GV; Millipore Corporation) and degassed. The flow rate was set at $1.0 \mathrm{ml} / \mathrm{min}$. Values were calculated on the basis of peak area compared with standard solutions.

Colonic motility. Colonic motility was studied as described previously (Li et al., 2006). Briefly, the animals were anesthetized with isoflurane 
(Baxter Pharmaceutical Products). A glass bead (3 $\mathrm{mm}$ in diameter) was pushed into the colon to a distance of $2 \mathrm{~cm}$ from the anal verge. The time required for expulsion of the glass bead was measured and taken as an estimate of colonic motility.

Total gastrointestinal transit time. Carmine red, which cannot be absorbed from the lumen of the gut, was used to study total GI transit time (Kimball et al., 2005). A solution of carmine red (300 $\mu$ l; 6\%; SigmaAldrich) suspended in 0.5\% methylcellulose (Sigma-Aldrich) was administered by gavage through a 21 gauge round-tip feeding needle. The time at which gavage took place was recorded as $T_{0}$. After gavage, fecal pellets were monitored at $10 \mathrm{~min}$ intervals for the presence of carmine red. Total GI transit time was considered as the interval between $T_{0}$ and the time of first observance of carmine red in stool.

Gastric emptying and small intestine transit. Mice were fasted overnight in cages that lacked bedding. Water was withdrawn $3 \mathrm{~h}$ before the experiment. A solution containing rhodamine B dextran $(100 \mu \mathrm{l} ; 10 \mathrm{mg} / \mathrm{ml}$ in $2 \%$ methylcellulose; Invitrogen) was administered to each mouse by gavage through a 21-gauge round-tip feeding needle. Animals were killed $15 \mathrm{~min}$ after gavage; the stomach, small intestine, cecum, and colon were collected in $0.9 \% \mathrm{NaCl}$. The small intestine was divided into 10 segments of equal length, and the colon (used to obtain total recovered rhodamine B fluorescence) was divided in half. Each piece of tissue was then transferred into a $14 \mathrm{ml}$ tube containing $4 \mathrm{ml}$ of $0.9 \% \mathrm{NaCl}$, homogenized, and centrifuged $(2000 \times g)$ to obtain a clear supernatant. Rhodamine fluorescence was measured in $1 \mathrm{ml}$ aliquots of the supernatant (VersaFluor Fluorometer; Bio-Rad Laboratories). The proportion of the rhodamine B dextran that emptied from the stomach was calculated as [(total recovered fluorescence - fluorescence remaining in the stomach)/(total recovered fluorescence) $] \times 100$. Small intestinal transit was estimated by the position of the geometric center of the rhodamine B dextran in the small bowel (Miller et al., 1981). For each segment of the small intestine (1-10), the geometric center $(a)$ was calculated as follows: $a=$ (fluorescence in each segment $\times$ number of the segment)/(total fluorescence recovered in the small intestine). The total geometric center is $\Sigma$ ( $a$ of each segment). Total geometric center values are distributed between 1 (minimal motility) and 10 (maximal motility).

Immunoselection and tissue culture. In vitro studies were used to investigate the ability of 5-HT to influence the development of enteric neurons from their neural crest-derived precursors. Crest-derived cells were immunoselected from E16 mouse gut with antibodies to the common neurotrophin receptor as described previously (Chalazonitis et al., 2004). Briefly, the bowel was dissociated with collagenase to yield a single-cell suspension. The suspended cells were exposed, sequentially, to antibodies to $\mathrm{p} 75^{\mathrm{NTR}}$, which recognize a region of the extracellular domain (amino acids 43-161) and react with p75 ${ }^{\text {NTR }}$ of both rats and mice (Huber and Chao, 1995) (donated by Moses Chao, Skirball Institute, New York University, New York, NY) and then to secondary antibodies coupled to magnetic beads (Miltenyi Biotec); the antibody decorated enteric crest-derived cells were finally selected with a magnet and separation columns (Miltenyi Biotec).

Immunoselected cells destined for the demonstration of $\mathrm{HuC} / \mathrm{D}$ immunoreactive (total neurons) and $\mathrm{TH}$-immunoreactive (dopaminergic) neurons were plated at a density of $1.2 \times 10^{5}$ cells $/ \mathrm{ml}$ onto $12-\mathrm{mm}-$ diameter glass coverslips (catalog \#1001; RESY), which were coated with poly-D-lysine, rat tail collagen, and laminin as described previously (Chalazonitis et al., 1998). Immunoselected cells destined for analysis of dopamine were plated at a density of $110 \times 10^{3}$ cells $/ \mathrm{ml}$ onto $35-\mathrm{mm}$ diameter TC dishes (Falcon). All cultures were maintained in a serumfree defined medium [basic Brazeau medium (BBM)] (Ziller et al., 1983). At the time of plating, the medium was supplemented with $20 \%$ horse serum to promote adherence of cells to the substrate. After $18 \mathrm{~h}$, this medium was changed to serum-free BBM. Cultures were maintained for $6 \mathrm{~d}$, and they were fed with fresh medium on day 4 . In all experiments, glial cell line-derived neurotrophic factor (GDNF) (rat recombinant; R \& D Systems) was added to the medium at $10 \mathrm{ng} / \mathrm{ml}$ at the time of plating and was present throughout the subsequent culture period. GDNF was added because enteric neuronal development is known to be GDNF dependent. Cultures were supplemented with the TPH inhibitor parachlorophenylalanine (PCPA) $(1.0 \mu \mathrm{g} / \mathrm{ml}$; Sigma-Aldrich) to ensure that
Table 2. Primary antibodies for immunocytochemistry

\begin{tabular}{llll}
\hline Antigen & Antibody & Dilution & Source \\
\hline CGRP & Goat polyclonal & $1: 800$ & Biogenesis \\
GABA & Rabbit polyclonal & $1: 2500$ & Sigma \\
HuC/D & Mouse monoclonal & $1: 20$ & Invitrogen \\
nNOS & Rabbit polyclonal & $1: 500$ & Santa Cruz Biotechnology \\
SERT & Rabbit polyclonal & $1: 500$ & Randy Blakely, \#48 ${ }^{a}$ \\
TH & Sheep polyclonal & $1: 800$ & Millipore Corporation \\
\hline
\end{tabular}

${ }^{a}$ Vanderbilt University, Nashville, TN; 48 is lot number of the antibody.

endogenous 5-HT, synthesized within the cultures, would not confound results. Cultures were maintained with or without $5-\mathrm{HT}(1 \mu \mathrm{g} / \mathrm{ml})$.

Immunocytochemistry. $\mathrm{HuC} / \mathrm{D}, \mathrm{TH}, \mathrm{GABA}$, neuronal nitric oxide synthase (nNOS), and CGRP were located immunocytochemically to determine the abundance of total, dopaminergic, GABAergic, nitrergic, and CGRP-expressing enteric neurons in TPH1KO, TPH2KO, and TPH1/ $2 \mathrm{dKO}$ mice and their respective WT littermates. SERT immunoreactivity was also investigated to determine whether or not it is coincident with TH immunoreactivity in the myenteric plexus. In each experimental group, tissue samples were collected from ilea of six to eight animals, fixed with $4 \%$ formaldehyde for $1.5 \mathrm{~h}$, and washed in PBS. Whole-mount preparations of longitudinal muscle with attached myenteric plexus (LMMP) were prepared by dissection. Cultured cells were fixed with $4 \%$ formaldehyde for $30 \mathrm{~min}$ and washed in PBS. Preparations were blocked with $10 \%$ normal horse serum for $30 \mathrm{~min}$ at room temperature and then incubated for 48 or $72 \mathrm{~h}$ at $4^{\circ} \mathrm{C}$ with primary antibodies (Table 2). Bound primary antibodies were visualized, respectively, with streptavidin-Alexa Fluor 594 for mouse monoclonal antibodies and donkey antibodies to goat, rabbit, or sheep IgG coupled to Alexa Fluor 350, 488, or 594 (diluted 1:200; Invitrogen). Preparations were washed with PBS, mounted in buffered glycerol, and examined with a Leica CTR 6000 microscope. Images were obtained with a cooled CCD camera and analyzed with computer assistance (Velocity 5.4 imaging software; Improvision). To count the numbers of $\mathrm{HuC} / \mathrm{D}$-immunoreactive cells in each LMMP preparation, a motorized stage under computer control was used to scan and collect images with a $40 \times$ objective covering the entirety of a $10 \mathrm{~mm}^{2}$ area. To count the numbers of CGRP-, nNOS-, and TH-immunoreactive cells, a similar procedure was used, except that images were collected with a $20 \times$ objective and that an area of $30 \mathrm{~mm}^{2}$ was scanned. The higher magnification was needed for $\mathrm{HuC} / \mathrm{D}$-immunoreactive cells to ensure that overlapping cells could be distinguished. The lower magnification was advantageous for $\mathrm{TH}$-immunoreactive cells, which are widely separated and relatively rare, because the cells were scattered and large numbers could be imaged for statistical reliability. The collected images were processed using a computer running Velocity 5.6 software to determine the numbers of immunoreactive cells of each type, which were presented as cells per square millimeter. TH-immunoreactive terminal axons in the myenteric plexus of ileum of four TPH2KO and four WT mice were examined to study the effects of TPH2KO on the density of extrinsic sympathetic terminals. Sympathetic axons are far more abundant that dopaminergic axons in the myenteric plexus. Their large varicosities and coarse structure also distinguish sympathetic from dopaminergic axons. Dopaminergic neurons, moreover, are primarily located in the submucosal plexus. In each preparation, three images were obtained with a $40 \times$ objective. The total area occupied by TH-immunoreactive terminals in each image was obtained with computer assistance (Volocity 5.6 software; Improvision/PerkinElmer Life and Analytical Sciences).

Statistical analysis. Differences between means were compared by oneway ANOVA or, when only two means were compared, Student's $t$ test. A value of $p<0.05$ was considered significant.

\section{Results}

TPH deletion alters intestinal motility

To determine the effects of selective deletion of mucosal and neuronal 5-HT on GI motility, measurements were made of total GI transit time (Fig. 1A), gastric emptying (Fig. 1B), small intestinal transit (Fig. 1C), and colonic motility (Fig. $1 D$ ) in TPH1KO, 
A

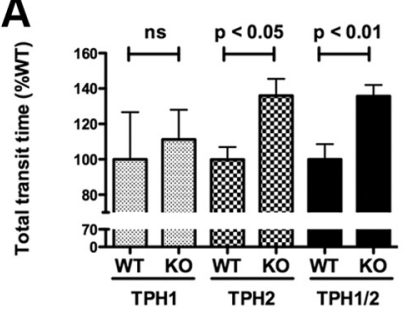

B
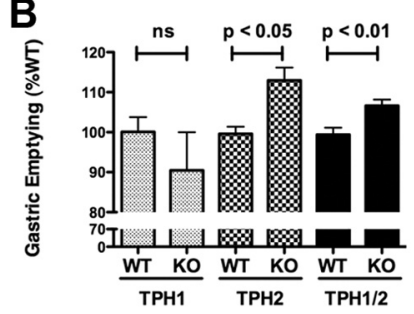

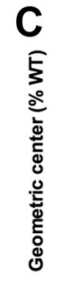

D
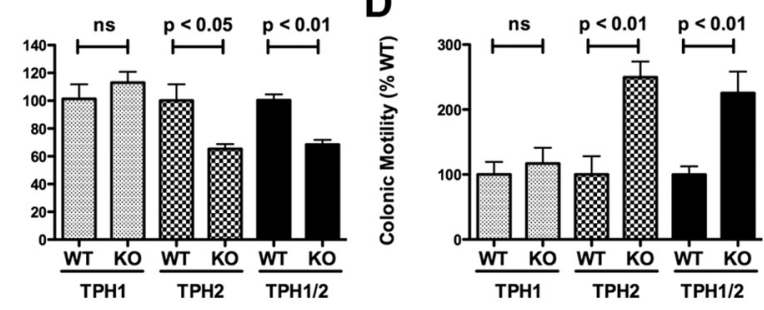

Figure 1. Total $\mathrm{GI}$ transit time, small intestine transit, and colonic motility are decreased but gastric emptying is accelerated in mice that lack TPH2 or TPH1 and TPH2. A, Carmine red was administered orally, and the time to development of red stools was noted. GI transit time in TPH1K0, TPH2K0, and TPH1/2dK0 mice was compared, respectively, with that of wild-type littermates. Total GI transit time was increased (slower than littermates) in TPH2KO and TPH1/ $2 \mathrm{dKO}$ animals; however, the total GI transit time in TPH1KO mice did not differ from that of their wild-type littermates. Total GI transit time in TPH1/2dKO animals was not different from that in mice lacking only TPH2. B, Gastric emptying was measured after gavage of rhodamine dextran. The percentage of administered rhodamine dextran that emptied from the stomach in $15 \mathrm{~min}$ was determined in TPH1KO, TPH2KO, and TPH1/2dKO mice and compared with that of their respective wild-type littermates. The proportion of gastric contents that emptied was greater in $\mathrm{TPH} 2 \mathrm{KO}$ and TPH1/2dKO animals than in the respective littermates; however, gastric emptying in TPH1KO mice did not differ from that in their wild-type littermates. Gastric emptying in $\mathrm{TPH} 1 / 2 \mathrm{dKO}$ animals was not different from that in mice lacking only TPH2. C, Small intestinal transit was studied by measurement of geometric center of rhodamine dextran. The numbers of the geometric center, 1-10, represent slow to fast small intestine transit. Small intestinal transit was significantly slower in $\mathrm{TPH} 2 \mathrm{KO}$ and $\mathrm{TPH} 1 / 2 \mathrm{dKO}$ animals than in their respective wild-type littermates; however, small intestinal transit in TPH1KO mice did not differ significantly from that of their wild-type littermates. Small intestinal transit in TPH1/2dKO animals was not different from that in mice lacking only TPH2. D, Colonic motility was estimated by measuring the time required to expel a glass bead inserted into the rectum for a distance of 2 $\mathrm{cm}$. This time was significantly greater (slower motility) in TPH2KO and TPH1/2dKO animals than in their respective wild-type littermates; however, the time to expel the bead in TPH1KO mice did not differ significantly from that in their wild-type littermates. The time required to expel the bead in TPH1/2dKO mice was not significantly different from that in mice lacking only $\mathrm{TPH} 2$. ns, Not significant.

TPH2KO, and TPH1/2dKO mice. The time to first appearance of a non-absorbed dye (carmine red) in fecal pellets was used to estimate total GI transit, and the expulsion of glass beads inserted into the rectum was used to evaluate colonic motility. These tests were performed first because they do not require that animals be killed and thus can be repeated. After total GI transit time and colonic motility had been determined in each animal, the rate at which rhodamine dextran was emptied from the stomach and the geometric center of rhodamine dextran in the small intestine were determined. Comparisons were made between littermates so that the natural slowing of motility that occurs in mice as a function of age (Liu et al., 2009) would not confound observations.

Total GI transit time in TPH1KO mice did not differ significantly from that in their WT littermates (Fig. 1A). In contrast, total GI transit time was found to be significantly longer in both $\mathrm{TPH} 2 \mathrm{KO}$ and TPH $1 / 2 \mathrm{dKO}$ animals than in the WT littermate controls of each (Fig. $1 A$ ). As was the case for total GI transit, the rate of gastric emptying in TPH1KO mice was not significantly different from that in their WT littermates (Fig. 1B). Surpris- ingly, however, the rate of gastric emptying was more rapid in $\mathrm{TPH} 2 \mathrm{KO}$ and $\mathrm{TPH} 1 / 2 \mathrm{dKO}$ mice than in the corresponding WT littermates (Fig. $1 B$ ), despite the net increase in total GI transit time in TPH2KO and TPH $1 / 2 \mathrm{dKO}$ animals (Fig. $1 A$ ). Once emptied from the stomach, rhodamine dextran was propelled down the small intestine at approximately the same rate in $\mathrm{TPH} 1 \mathrm{KO}$ and littermate control mice (Fig. 1C); however, the propulsion of rhodamine dextran down the small intestine was significantly slower in TPH2KO and TPH1/2dKO mice than in their WT littermates (Fig. 1C). This pattern was continued in the colon. The rate at which beads were ejected from the anus was not significantly different in TPH1KO mice than in their WT littermates (Fig. $1 D$ ) but was significantly slower than littermate controls in both TPH2KO and TPH1/2dKO animals (Fig. 1D). These observations suggest that the genetic deletion of TPH1 exerts little effect on constitutive motility of the stomach or small or large intestine. In contrast, the genetic deletion of $\mathrm{TPH} 2$, which in terms of GI motility appears to be the equivalent of the double knock-out of TPH1 and TPH2, slows transit in the intestines (Fig. $1 C, D$ ) but accelerates the rate of gastric emptying (Fig. $1 B$ ). The net effect of the deletion of TPH2 is to increase GI transit time (Fig. 1A); therefore, overall, the more rapid emptying of the stomach in TPH2KO and TPH1/2dKO mice does not compensate for the slowing of proximodistal transport of intestinal contents. Studies with pharmacological antagonists and depletion of 5-HT have previously suggested that intrinsic serotonergic neurons inhibit gastric emptying by providing an excitatory drive to neurons in a relaxant pathway (Bülbring and Gershon, 1967a; Mawe et al., 1989). The intraperitoneal injection of 5-HT (1 mg/ $\mathrm{kg}$ ) in WT mice, moreover, was also found to significantly delay gastric emptying $(p<0.01)$. In the absence of $5-\mathrm{HT}, 82.5 \pm 1.4 \%$ $(n=6)$ of gastric contents emptied within $15 \mathrm{~min}$, whereas in the presence of 5 -HT, only $56.3 \pm 6.1 \%(n=9)$ emptied within the same period of time. The effect of stimulation of gastric 5-HT receptors is thus opposite to that of depletion of 5-HT from gastric neurons.

\section{Effect of TPH1/2dKO on enteric dopaminergic neurons}

Because postmitotic serotonergic neurons coexist with stillproliferating ENCDCs, we tested the hypothesis that the earlydeveloping serotonergic neurons influence subsequent ENS development. If this were to occur, then we would expect that the total number of neurons in the ENS of TPH 2 and TPH1/2dKO would be different from that in WT mice. If only neuronal and not mucosal 5-HT were to affect neuronal development, the number of enteric neurons in TPH 2 and TPH1/2dKO would also be different from that in TPH1KO animals. If 5-HT were to promote neuronal development, then the deletion of TPH would reduce the number of enteric neurons, whereas if 5 - $\mathrm{HT}$ were to exert an inhibitory effect on enteric neuronal development, the deletion of TPH would increase the numbers of neurons in the ENS. Because 5-HT-dependent neurons were expected to be those born later than serotonergic neurons, we chose to examine the effects of the knock-out of TPH1 and TPH2 on enteric dopaminergic neurons, which are born perinatally (Li et al., 2004). $\mathrm{HuC} / \mathrm{D}$ and $\mathrm{TH}$ were demonstrated immunocytochemically, respectively, to identify the total neuronal population and dopaminergic neurons in the myenteric plexus. Neurons were counted in whole mounts of dissected laminar preparations of bowel wall.

The densities of neurons in the ileal myenteric plexus of TPH2KO mice $\left(258 \pm 20\right.$ neurons $\left./ \mathrm{mm}^{2}\right)$ and TPH1/2dKO mice $\left(239 \pm 24\right.$ neurons $\left./ \mathrm{mm}^{2}\right)$ were each found to be significantly $(p<0.01)$ lower than those in either of their WT littermates 
(respectively, $370 \pm 70$ and $387 \pm 27$ neurons $/ \mathrm{mm}^{2}$ ) (Fig. $2 A$; compare also $C$ with $D, G$ with $H)$. In contrast, neuronal density in TPH1KO mice ( $314 \pm 22$ neurons/ $\mathrm{mm}^{2}$ ) did not differ from that in their WT littermates (304 \pm 22 neurons $/ \mathrm{mm}^{2}$ ) (Fig. 2A; compare also $K$ with $L$ ). These observations are compatible with the idea that neuronal 5-HT promotes the development and/or survival of enteric neurons. The density of $\mathrm{TH}$-immunoreactive dopaminergic neurons in the same regions of TPH2KO $(0.49 \pm 0.18$ neurons/ $\left.\mathrm{mm}^{2}\right)$ and $\mathrm{TPH} 1 / 2 \mathrm{dKO}(0.44 \pm 0.12$ neurons $/ \mathrm{mm}^{2}$ ) mice were also significantly $(p<0.001)$ lower than those in their WT littermates (respectively, $1.90 \pm$ 0.18 and $2.10 \pm 0.14$ neurons $/ \mathrm{mm}^{2}$ ) (Fig. $2 B$; compare also $E$ with $F, I$ with $J$ ). The reduction relative to $\mathrm{WT}$ in dopaminergic neurons was thus much greater than that in total neurons in TPH2KO and TPH1/ $2 \mathrm{dKO}$ mice (Fig. 2, compare $A, B$ ); in WT mice, $\mathrm{TH}$ neurons were $0.5 \%$ of the total myenteric population, but in both $\mathrm{TPH} 2 \mathrm{KO}$ and $\mathrm{TPH} 1 / 2 \mathrm{dKO}$ mice, this percentage fell to $0.2 \%$ of the reduced total number of neurons $(p<0.001)$. The proportion of neurons in the ENS that are dopaminergic is highly strain dependent and much higher in CD-1 (Li et al., 2004; Chalazonitis et al., 2008) than in mice with the 129S5/SvEvBrd and C57BL/6J hybrid background used in the current study. The reduction in dopaminergic neurons in TPH $2 \mathrm{KO}$ and TPH $1 / 2 \mathrm{dKO}$ mice, therefore, transcended that of the total population and was, consequently, a selective phenomenon. Again, as was the case with total neurons, the density of TH-immunoreactive neurons in TPH1KO mice $\left(2.26 \pm 0.32\right.$ neurons $/ \mathrm{mm}^{2}$ ) and the proportion of total neurons $(0.7 \%)$ were not significantly different from the neuronal density (1.90 \pm 0.32 neurons/ $\mathrm{mm}^{2}$ ) or proportion of total neurons $(0.7 \%)$ in their WT littermates (Fig. 2B; compare also $M$ with $N$ ).

To help verify that the reduction in $\mathrm{TH}-$ immunoreactive neurons in $\mathrm{TPH} 2 \mathrm{KO}$ and $\mathrm{TPH} 1 / 2 \mathrm{dKO}$ mice was attributable to a loss of enteric dopaminergic neurons and not to a immunoreactive $\mathrm{TH}$ within existing neurons, enteric transcripts encoding TH (Fig. $3 A$ ) and DAT (Fig. 3B), which is a dopaminergic neuronal marker, were measured in the ileum of TPH $1 \mathrm{KO}$, TPH2KO, TPH1/2dKO, and their respective WT mice. The abundance of transcripts encoding both TH (Fig. 3A) and DAT (Fig. $3 B$ ) was significantly lower in the ileum of TPH $2 \mathrm{KO}$ and TPH $1 / 2 \mathrm{dKO}$ animals than in the ileum of their WT lit-
A

B
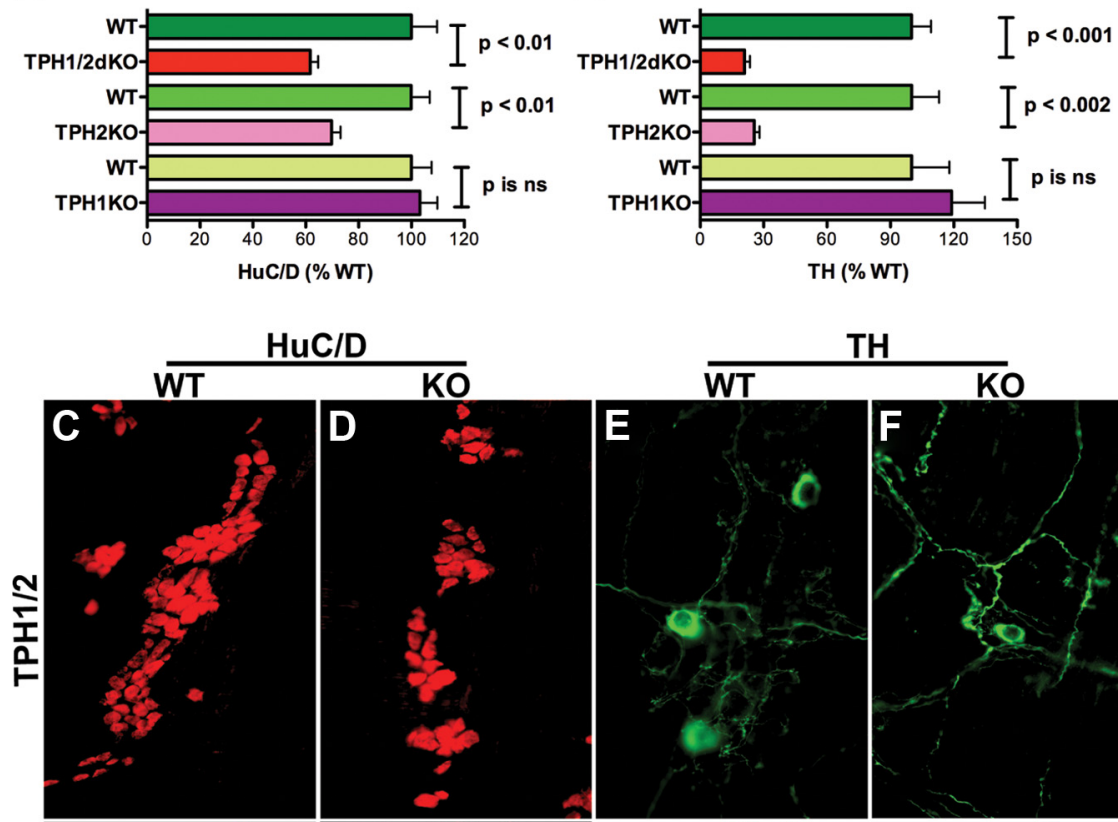

HuC/D
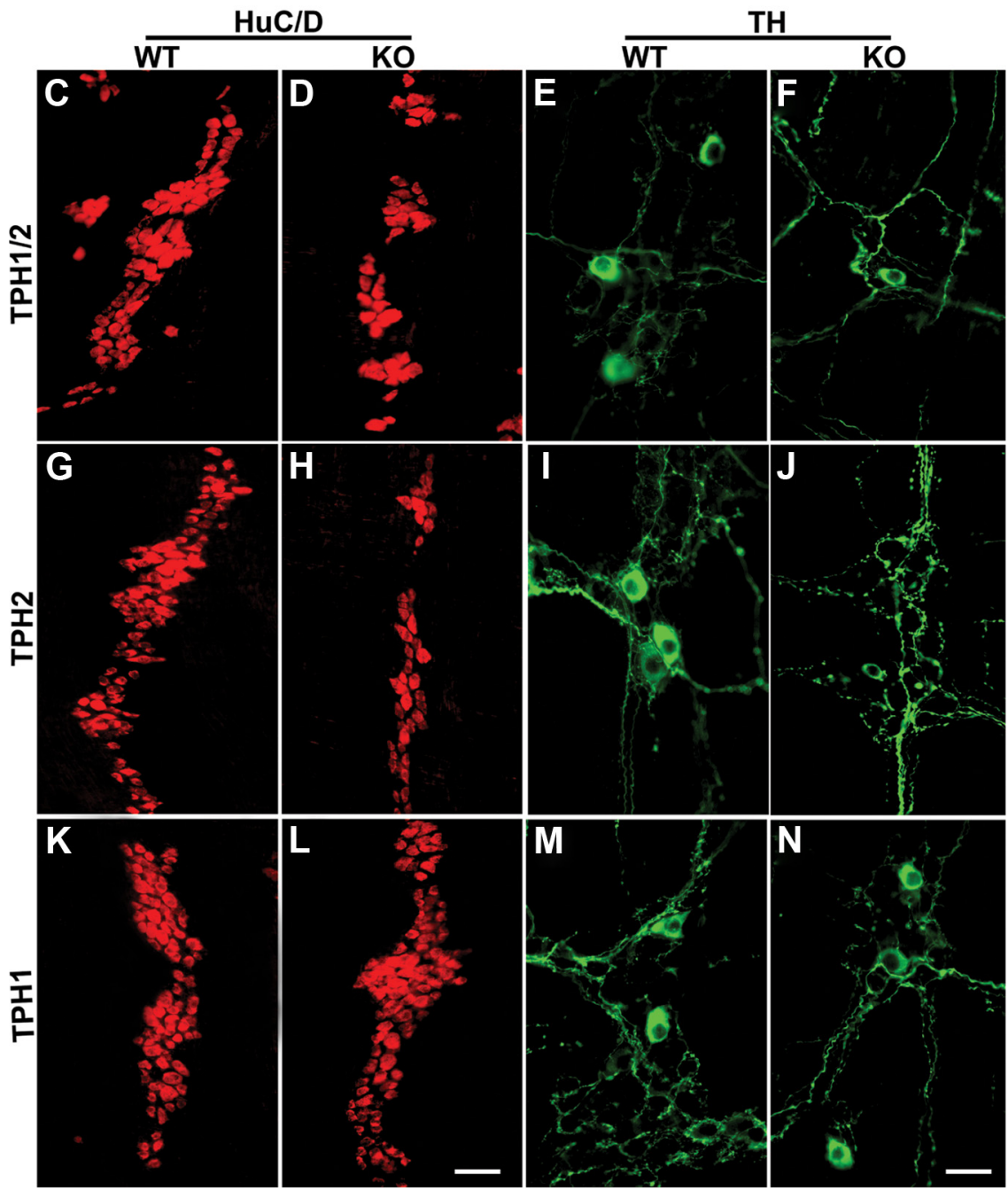

Figure 2. Numbers of total and dopaminergic enteric neurons are decreased in mice that lack TPH2 or TPH1 and TPH2. A, The total number of neurons was obtained from counts made in whole mounts of dissected laminar preparations of longitudinal muscle with adherent myenteric plexus. The immunocytochemical detection of HuC/D was used as a neuronal marker. The numbers of total enteric neurons in TPH1K0, TPH2K0, and TPH1/2dKO mice were compared, respectively, with those of their wild-type littermates. Significantly fewer total neurons were found in TPH2KO and TPH1/2dKO animals than in their wild-type littermates; however, the total number of neurons in TPH1KO mice was not significantly different from that in their wild-type littermates. The number of neurons in TPH1/2dKO animals did not significantly differ from that in mice lacking only TPH2. $\boldsymbol{B}$, TH was identified immunocytochemically and used as a marker for enteric dopaminergic neurons. Preparations were the same as used to investigate total neuronal numbers. Again, the numbers of TH-immunoreactive neurons in TPH1KO, TPH2KO, and TPH1/2dKO mice were compared with those of their respective wild-type littermates. The numbers of enteric dopaminergic neurons were significantly reduced in TPH2KO and TPH1/2dKO animals; however, the numbers of dopaminergic neurons in TPH1KO mice did not differ significantly from that of their wild-type littermates. The numbers of dopaminergic neurons in TPH1/2dKO animals was not significantly different from those in mice lacking only TPH2. Although both total and dopaminergic neurons were reduced in mice lacking TPH2 and TPH1 and TPH2, the deficit in dopaminergic neurons was more severe than that in total neurons. C, D, Neurons immunostained with antibodies to HuC/D in wild-type littermates ( $\boldsymbol{C}$ and TPH1/2dKO mice (D). $\boldsymbol{E}, \boldsymbol{F}$, Neurons immunostained with antibodies to TH in wild-type littermates $(\boldsymbol{E})$ and TPH1/2dKO mice $(\boldsymbol{F}) . \boldsymbol{G}, \boldsymbol{H}$, Neurons immunostained with antibodies to HuC/D in wild-type littermates $(\boldsymbol{G})$ and TPH2KO mice $(\boldsymbol{H}) . \boldsymbol{I}, \boldsymbol{J}$, Neurons immunostained with antibodies to TH in wild-type littermates $(\boldsymbol{I})$ and TPH2KO mice $(\boldsymbol{F})$. Neurons immunostained with antibodies to HuC/D in wild-type littermates $(\boldsymbol{K})$ and TPH1KO mice $(\boldsymbol{L})$. $\boldsymbol{M}, \boldsymbol{N}$, Neurons immunostained with antibodies to TH in wild-type littermates $(\boldsymbol{M})$ and TPH1KO mice $(\boldsymbol{N})$. Scale bars: $\boldsymbol{L}, 50 \mu \mathrm{m}$ (for all HuC/D images); $N$, $25 \mu \mathrm{m}$ (for all TH images). ns, Not significant. 

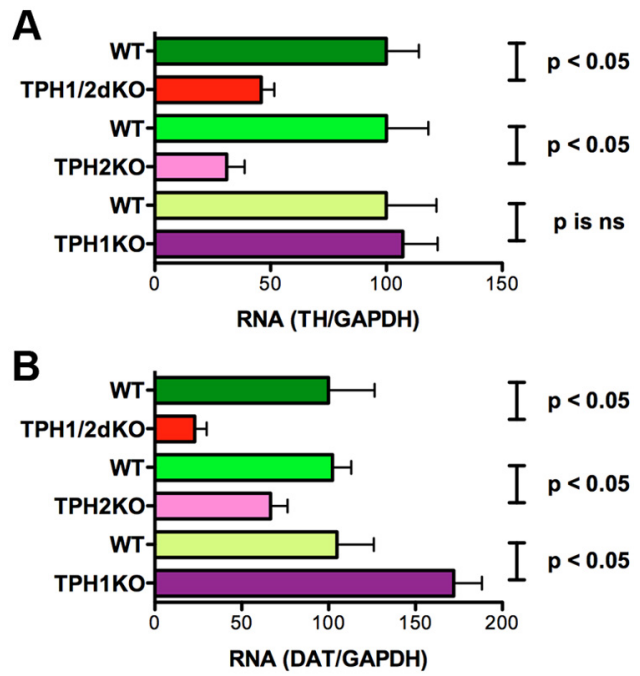

Figure 3. Transcripts encoding TH and DAT are downregulated in the ileum of mice that lack TPH2 or TPH1 and TPH2. Real-time PCR was used to analyze TH and DAT expression quantitatively in the ileum. $A$, Expression of TH in TPH1KO, TPH2KO, and TPH1/2dKO mice was compared, respectively, with that in their wild-type littermates; data are expressed as percentage WT. Transcripts encoding TH were significantly less abundant in TPH2KO and TPH1/2dKO animals than in their wild-type littermates. The abundance of transcripts encoding TH in TPH1KO mice, however, did not differ significantly from that in their wild-type littermates. TH expression in TPH1/2dKO animals was not significantly different from that in mice lacking only TPH2. $\boldsymbol{B}$, Expression of DAT in TPH1K0, TPH2K0, and TPH1/2dKO mice was compared, respectively, with that in their wild-type littermates; data are expressed as percentage WT. The abundance of transcripts encoding DAT in TPH2KO and TPH1/2dKO animals was significantly less than that in their wild-type littermates. The abundance of transcripts encoding DAT in TPH1KO mice, however, was greater than that in their wild-type littermates. DAT expression in TPH1/2dKO animals was not significantly different from that in mice lacking only TPH2. ns, Not significant.

termates. In contrast, no decrease was seen in the ileal abundance of transcripts encoding either TH (Fig. $3 A$ ) or DAT (Fig. $3 B$ ) in $\mathrm{TPH} 1 \mathrm{KO}$ mice. Surprisingly, the deletion of TPH1 actually led to a significant increase in the expression of DAT (Fig. 3B). The effect of the double knock-out of TPH1 and TPH2 on expression of TH and DAT in the colon was similar to that in the ileum; again, the abundance of transcripts encoding $\mathrm{TH}$ and DAT was significantly lower in TPH1/2dKO than in WT mice. The relative abundance of transcripts encoding $\mathrm{TH}$ in the colon of TPH1/ $2 \mathrm{dKO}$ mice was $56.4 \pm 11.2 \%$ of WT $(p<0.05)$, whereas that encoding DAT was only $21.12 \pm 5.60 \%$ of WT $(p<0.03)$. These observations are consistent with the hypothesis that dopaminergic neuronal development and/or maintenance are dependent on neuronal rather than mucosal 5-HT.

\section{5-HT promotes the in vitro development/survival of dopaminergic neurons}

The hypothesis that 5-HT stimulates the development and/or survival of enteric dopaminergic neurons was tested directly with ENCDCs isolated from E16 fetal mouse gut by immunoselection with antibodies to $\mathrm{p} 75^{\mathrm{NTR}}$. E16 was chosen for the analysis because the generation of enteric serotonergic neurons (E8.5-E15) is known to be complete by that time (Pham et al., 1991); nevertheless, the ENS at E16 still contains ENCDCs capable of forming dopaminergic neurons, the birth of which does not begin until the perinatal period ( $\mathrm{Li}$ et al., 2004). The isolated ENCDCs were cultured for $6 \mathrm{~d}$ in the absence or presence of exogenous 5-HT (1 $\mu \mathrm{M})$. The TPH inhibitor PCPA $(1 \mu \mathrm{M})$ was added to the medium to prevent biosynthesis of endogenous 5-HT. HPLC was used to measure the amounts of 5-HT and DA present in each culture. A small concentration of 5 -HT was detected in control cultures $(17 \pm 4 \%$ of that recovered in cultures treated with $5-\mathrm{HT} ; p<$ 0.01 ) despite the presence of PCPA. Cultures not used for the measurement of amines were fixed for the immunocytochemical detection of $\mathrm{TH}$, which was used as a marker for dopaminergic neurons. Antibodies to $\mathrm{HuC} / \mathrm{D}$ were used to demonstrate the total population of neurons in these cultures. Significantly more DA was found in 5-HT-treated cultures $(11.5 \pm 2.2 \mathrm{pmol} / \mathrm{ml})$ than in matched control cultures exposed only to vehicle (3.6 \pm $0.8 \mathrm{pmol} / \mathrm{ml} ; p<0.01 ; n=12)$. The addition of 5 -HT also increased both the number of TH-immunoreactive (dopaminergic) neurons (Fig. $4 \mathrm{~A}$ ) and the total number of neurons developing/surviving in vitro (Fig. $4 \mathrm{~B}$ ). The increase in dopaminergic neurons was approximately equal to the increase in total neurons; therefore, the proportion of neurons that were dopaminergic was not significantly changed by the presence of 5-HT in the culture medium (Fig. 4C). Neurons were found in small aggregates in both vehicle-treated (Fig. 4D) and 5-HT-treated (Fig. 4E) cultures. The cell bodies of TH-immunoreactive (dopaminergic) neurons were found within the neuronal aggregates (Fig. 4F-I). In vehicle-treated cultures, few or no neurites projected from dopaminergic neurons (Fig. $4 F$ ); however, in the presence of 5 -HT, dopaminergic neurons extended neurites that projected to adjacent neuronal aggregates (Fig. $4 G$ ) or onto the adjacent substrate in which they appeared to terminate in a series of varicosities (Fig. $4 \mathrm{H}$ ). Some of the dopaminergic neurites in 5-HT-treated cultures were very long and branched extensively (Fig. 4I). These observations suggest that, when added to isolated ENCDCs at E16, 5-HT promotes the development/ survival of enteric neurons, including those that acquire a dopaminergic phenotype. In addition to its effects on development/survival, 5-HT also appeared to enhance neurite extension. The development-enhancing effects of 5-HT, however, are not restricted to dopaminergic neurons.

\section{Enteric DA and 3-methoxy 4-hydroxyvanillic acid levels are} higher in the ileum of SERTKO than WT mice

SERTKO mice were studied as a gain-of-function model to test the idea that endogenous 5-HT acts on dopaminergic neurons in vivo. Because SERT is primarily responsible for terminating 5-HT signaling in both the ENS and the mucosa, the effects of 5-HT are potentiated and prolonged in SERTKO animals. Levels of DA and its metabolites were thus measured and compared in SERTKO mice and their WT littermates. Two enzymes are primarily responsible for the catabolism of DA, monoamine oxidase (MAO) and catechol-O-methyl transferase (COMT) (Molinoff and Axelrod, 1971). MAO catabolism of DA leads to the production of 3,4-dihydroxyphenylacetic acid (DOPAC), which can be converted by COMT to 3-methoxy 4-hydroxyvanillic acid (HVA). COMT can also convert DA to 3-methoxytyramine, which MAO, in turn, converts to HVA. The major metabolite of DA is thus HVA, which is also a specific metabolite of DA and not produced after catabolism of norepinephrine or epinephrine. Levels of DA, DOPAC, and HVA were measured in the ileum, colon, and brain of SERTKO mice and their WT littermates. Although the DA concentration was not significantly changed in the ileum or colon of SERTKO mice (Fig. 5A), the level of HVA was significantly increased in the ileum but not the colon of SERTKO animals (Fig. $5 B)$. The total levels of DA and its metabolites HVA and DOPAC were also significantly greater in the ileum of SERTKO mice than in their WT littermates, although again, the increase in the colon did not reach statistical significance (Fig. 5C). The level of 5-HT in SERTKO mice did not differ from that of WT animals in either 
A
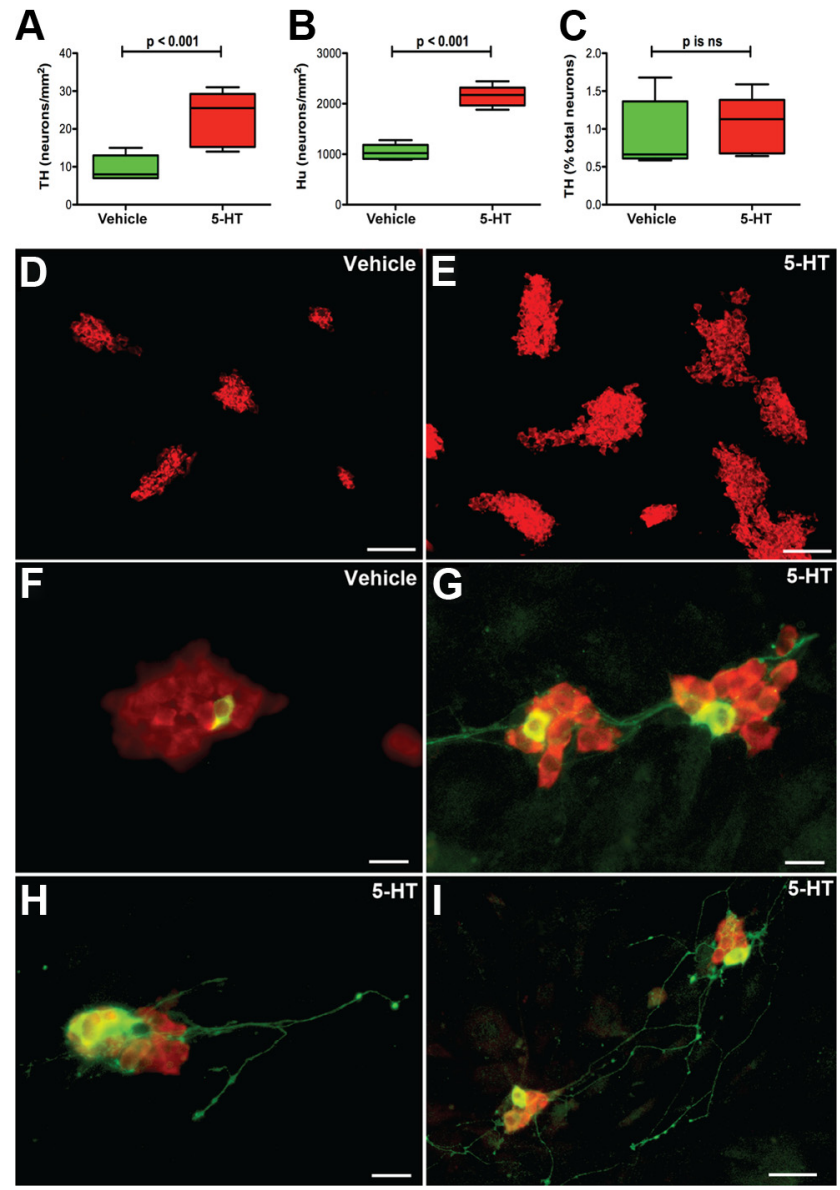

Figure 4. 5-HT stimulates the development and/or survival of total and dopaminergic enteric neurons in cultures of ENCDCs isolated from E16 fetal mouse gut. ENCDCs were immunoselected with antibodies to $75^{\text {NTR }}$ and cultured for $6 \mathrm{~d}$ in the absence or presence of exogenous 5 -HT $(1 \mu \mathrm{M})$. The TPH inhibitor PCPA $(1 \mu \mathrm{M})$ was added to the medium to prevent biosynthesis of endogenous 5-HT. A, TH was identified immunocytochemically and was used as a dopaminergic marker. The abundance of TH-immunoreactive neurons in 5-HT-treated cultures was significantly greater than that in control cultures exposed only to vehicle. $B, H u C / D$ was identified immunocytochemically and was used as a neuronal marker. The abundance of neurons in 5-HT-treated cultures was significantly greater than in control cultures exposed only to vehicle. C, Although numbers of both total neurons and dopaminergic neurons increased after the addition of 5-HT, the proportion of neurons that were dopaminergic was not significantly different in 5-HT-treated cultures from that of control cultures exposed only to vehicle. $\boldsymbol{D}, \boldsymbol{E}$, $\mathrm{HuC/D}$-immunoreactive neurons (red fluorescence) were found in small aggregates in both vehicle-treated $(\boldsymbol{D})$ and 5-HT-treated $(\boldsymbol{E})$ cultures. The numbers and the sizes of the aggregates, however, were both larger in 5-HT-treated cultures than in cultures exposed only to vehicle. $\boldsymbol{F}-\boldsymbol{I}$, Double-labeled immunocytochemistry was used to locate simultaneously the immunoreactivities of HuC/D and TH (green fluorescence). The cell bodies of TH-immunoreactive (dopaminergic) neurons were found within aggregates of HuC/D-immunoreactive neurons. $\boldsymbol{F}$, Vehicle-treated culture. A single dopaminergic neuron appears within an aggregate of HuC/Dimmunoreactive neurons. No dopaminergic neurites are visible. G, 5-HT-treated culture. Dopaminergic neurons are more numerous and extend $\mathrm{TH}$-immunoreactive neurites that project to adjacent neuronal aggregates. $\boldsymbol{H}, \boldsymbol{I}, 5$-HT-treated cultures. $H$, Dopaminergic neurites project from neurons within an aggregate to the adjacent substrate, in which they terminate in a series of varicosities. I, Some dopaminergic neurites in 5 -HT-treated cultures are very long and branch extensively. Scale bars: $\boldsymbol{D}, \boldsymbol{E}, 100 \mu \mathrm{m} ; \boldsymbol{F}-\boldsymbol{H}, 20 \mu \mathrm{m} ; \boldsymbol{I}, 50 \mu \mathrm{m}$. ns, Not significant.

the ileum or colon (Fig. 5D). There was a difference in the concentration of the 5-HT metabolite 5-hydroxyindoleacetic acid (5-HIAA), in the colon; however, in contrast to the increase in HVA in the SERTKO ileum, the concentration of 5-HIAA was significantly lower in the colon of SERTKO mice than in the colon of WT littermates (Fig. 5E). In SERTKO mice, moreover, the total of 5-HT and 5-HIAA was significantly lower in both the ileum and colon than in WT animals (Fig. $5 F$ ). The deletion of SERT thus tended to increase the metabolism and thus turnover of DA, primarily in the small intestine, but exerted an opposite effect on 5-HT. These observations are compatible with the idea that endogenous 5-HT release stimulates the activity of dopaminergic neurons in adult mice.

\section{The effect of TPH1/2dKO on SERT expression}

Because SERT is critical for the inactivation of 5-HT and its absence was found to affect the apparent turnover of DA, we investigated the expression of SERT in mice that lacked 5-HT. To do so, we measured the abundance of transcripts encoding SERT in the ileum and colon of TPH1/2dKO mice and in their WT littermates (Fig. 6). In WT mice, transcripts encoding SERT were significantly more abundant in the ileum than in the colon $(p<$ $0.05)$. In TPH $1 / 2 \mathrm{dKO}$ mice, however, the abundance of transcripts encoding SERT was found to be significantly lower than that of WT littermates, in both the ileum $(7.7 \pm 1.0 \%$ of WT; $p<$ $0.001)$ and the colon $(2.6 \pm 0.6 \%$ of WT; $p<0.001)$ (Fig. 6). SERT expression, therefore, is substantially downregulated in $\mathrm{TPH} 1 / 2 \mathrm{dKO}$ mice, in both the ileum, in which its WT expression is relatively high, and the colon, in which its WT expression is relatively low. This downregulation of SERT in TPH1/2dKO mice may be a compensatory response to the absence of 5-HT in these animals.

\section{Effect of TPH2KO on enteric GABAergic, nitrergic, and CGRP-expressing neurons}

The effects of TPH2KO on the development of enteric GABAergic, nitrergic, and CGRP-expressing neurons were analyzed. The numbers of GABAergic and nitrergic neurons in the myenteric plexus and those of CGRP-expressing neurons in the submucosal plexus were determined in WT and TPH2KO littermates. CGRPexpressing neurons were examined in the submucosal plexus because they are relatively rare in the myenteric and difficult to quantify in that plexus. LMMP preparations were triply immunostained to locate $\mathrm{HuC} / \mathrm{D}$ (Fig. $7 A, E)$ and TH (Fig. $7 B, F)$ simultaneously with that of GABA (Fig. 7C,G; merged images $D$, $H)$. GABAergic neurons constituted $5.3 \pm 0.4 \%$ of $\mathrm{HuC} / \mathrm{D}$ immunoreactive in WT mice but only $3.7 \pm 0.4 \%$ in TPH $2 \mathrm{KO}$ animals $(p<0.05)$. In neither WT nor TPH $2 \mathrm{KO}$ mice were the immunoreactivities of $\mathrm{TH}$ and GABA coincident. The densities of nitrergic neurons in the myenteric plexuses of WT (Fig. 7I) and TPH2KO (Fig. 7J) were also significantly reduced. The density of nitrergic neurons was $60.8 \pm 3.9 \mathrm{cells} / \mathrm{mm}^{2}$ in the myenteric plexus of WT mice and $47.0 \pm 3.9$ cells $/ \mathrm{mm}^{2}$ in that of TPH $2 \mathrm{KO}$ animals $(p<0.05)$; however, in contrast to dopaminergic and GABAergic neurons, the proportion of neurons in TPH2KO mice that were nitrergic $(17.8 \pm 2.8 \%)$ was not significantly different from WT $(16.4 \pm 2.3 \%)$. The density of CGRPexpressing cells was $19.3 \pm 0.9$ cells $/ \mathrm{mm}^{2}$ in the submucosal plexus of WT mice (Fig. $7 K$ ) but $14.3 \pm 0.9$ cells $/ \mathrm{mm}^{2}$ in TPH2KO mice (Fig. $7 L)(p<0.01)$. The density of CGRPexpressing cells in TPH $2 \mathrm{KO}$ mice was $\sim 74 \%$ of WT, and the proportion of total cells was $\sim 69 \%$, which was not significantly different from WT.

\section{Effect of TPH2KO on the density of sympathetic terminals in the ENS}

The density of sympathetic terminal axons, which are extrinsic to the gut, was measured in the myenteric plexus of the ileum of WT and $\mathrm{TPH} 2 \mathrm{KO}$ mice immunostained with antibodies to $\mathrm{TH}$. The proportion of the area of each LMMP preparation occupied by 
A
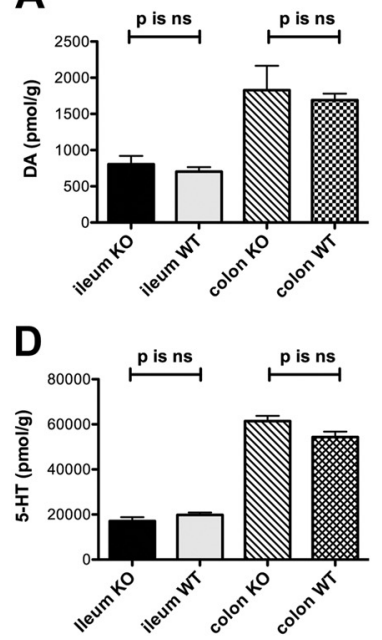

B

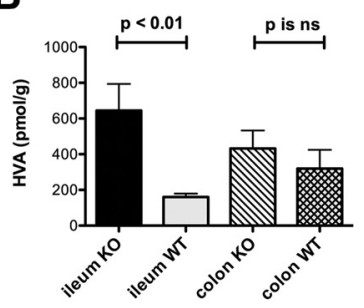

E

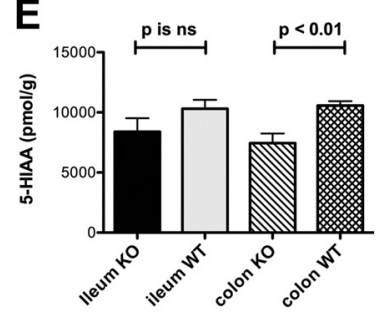

C

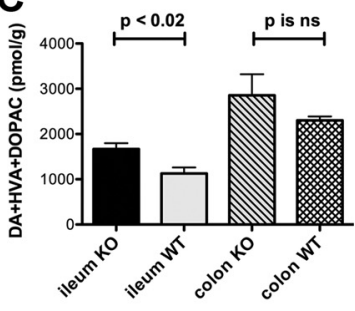

$F$

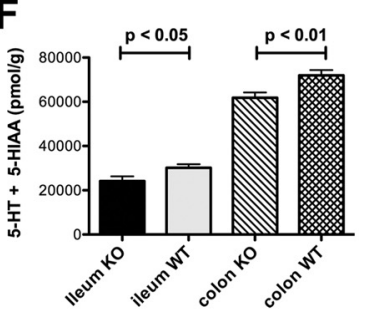

Figure 5. Enteric levels of DA and HVA are higher in the ileum of SERTKO than in the ileum of WT littermates. HPLC with electrochemical detection was used to measure levels of DA, DOPAC, and HVA in the ileum, colon, and brain of SERTKO mice and their WT littermates. $A$, DA levels in neither the ileum nor the colon of SERTKO mice were significantly different from those in the ileum and colon of their wild-type littermates. $\boldsymbol{B}$, The level of HVA was significantly greater than that of WT littermate controls in the ileum but not in the colon of SERTKO animals. C, The total level of DA plus its metabolites HVA and DOPAC was also significantly greater in the ileum of SERTKO mice than in their WT littermates, although again, the increase in the colon did not reach statistical significance. $\boldsymbol{D}$, The level of 5-HT in neither the ileum nor colon of SERTKO mice differed significantly from that in the ileum and colon of wild-type littermate controls. $\boldsymbol{E}$, The concentration of 5-HIAA, the 5-HT metabolite, in the colon was significantly lower in SERTKO mice than their WT littermates. F, In SERTKO mice, the total of 5-HT and 5-HIAA was significantly lower in both the ileum and colon than in WT animals. ns, Not significant.

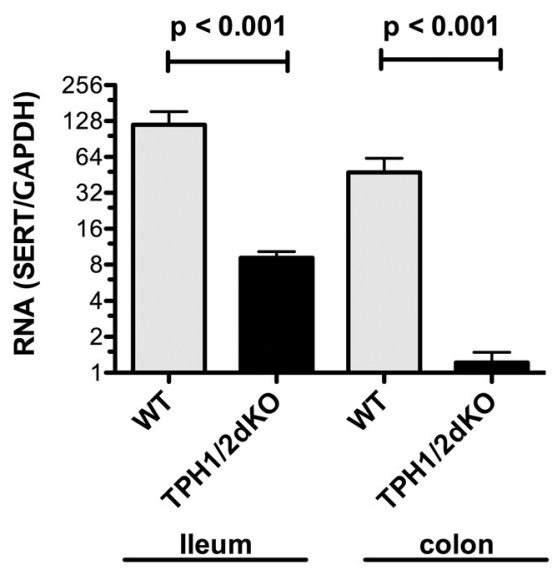

Figure 6. Transcripts encoding SERT are downregulated in the ileum and colon of TPH1/ $2 \mathrm{dKO}$ mice. Real-time PCR was used to quantify to abundance of transcripts encoding SERT. For each sample, the abundance of transcripts encoding SERT was normalized to that of GAPDH. Data are expressed as the ratio of transcripts encoding SERT to those of GAPDH. SERT expression in both ileum and colon of TPH1/2dKO animals was significantly lower than that in their wildtype littermates.

these terminals was measured. The proportional area occupied by sympathetic terminals in WT mice $(11.2 \pm 1.0 \%)$ did not differ significantly from that measured in TPH2KO animals $(10.8 \pm 1.0 \%)$.

\section{Expression of SERT and 5-HT receptor subtypes in ENCDCs}

Because observations suggest that enteric serotonergic neurons influence the development of neurons that are born later in ontogeny than they are, studies were performed to determine whether the ENCDC precursors of such neurons express 5-HT receptors that might respond to 5-HT putatively released from serotonergic neurons. The ENCDCs were immunoisolated with

antibodies to $\mathrm{p} 75^{\mathrm{NTR}}$ at E16. At this age, the birthdays of enteric serotonergic neurons have been completed, but those of dopaminergic, GABAergic, and CGRPexpressing neurons have not yet begun (Pham et al., 1991; Chalazonitis et al., 2008). Enteric nitrergic neurons represent a heterogeneous class, with some born early and others late. RT-PCR analysis revealed the presence in the isolated ENCDC preparations of transcripts encoding, in addition to $\mathrm{p} 75^{\mathrm{NTR}}, 5-\mathrm{HT}_{1 \mathrm{~A}}$, $5-\mathrm{HT}_{1 \mathrm{~B}}, \quad 15-\mathrm{HT}_{1 \mathrm{D}}, \quad 5-\mathrm{HT}_{1 \mathrm{~F}}, \quad 5-\mathrm{HT}_{2 \mathrm{~A}}$, $5-\mathrm{HT}_{2 \mathrm{~B}}, \quad 5-\mathrm{HT}_{3 \mathrm{~A}}, \quad 5-\mathrm{HT}_{4 \mathrm{~A}}, \quad 5-\mathrm{HT}_{4 \mathrm{~B}}$, $5-\mathrm{HT}_{4 \mathrm{E}}, 5-\mathrm{HT}_{4 \mathrm{~F}}, 5-\mathrm{HT}_{5 \mathrm{~A}}, 5-\mathrm{HT}_{5 \mathrm{~B}}, 5-\mathrm{HT}_{6}$, and $5-\mathrm{HT}_{7}$ receptors (Fig. $8 A$ ). Transcripts encoding SERT were also detected (Fig. 8A). Each of these transcripts was also observed in adult mouse brain, which was studied as a positive control (Fig. $8 A$ ).

\section{TH and SERT immunoreactivities are} not coincident in the myenteric plexus The immunoreactivities of SERT and TH were located simultaneously to determine whether enteric dopaminergic neurons contain SERT (Fig. 8B). Although none of the cell bodies of TH-immunoreactive dopaminergic neurons (Fig. $8 B$ ) contained coincident SERT immunoreactivity (Fig. $8 C$, merged image in $D$ ), a dense ring of varicose SERT-immunoreactive terminal axons surrounded each TH-immunoreactive neuron. Because SERT is a marker for serotonergic neurites, this configuration is consistent with the idea that enteric dopaminergic neurons receive a serotonergic innervation.

\section{Discussion}

Hormonal (Yadav et al., 2008), paracrine, and neurocrine functions have been ascribed to 5-HT in the gut (Gershon and Tack, 2007). Because of the massive size discrepancy between EC and neuronal 5-HT pools, EC cells have been assumed to be more important (Spiller, 2008); nevertheless, current data suggest that ENS development and constitutive GI motility depend more on enteric neuronal 5-HT than on that from EC cells. The defects in ENS development that occur when neuronal 5-HT is lacking complicate interpretation of the abnormal GI motility of TPH2KO mice. ENS defects and loss of serotonergic neurotransmission could each contribute to abnormal motility in adult animals.

The idea that the gut contains serotonergic neurons has been controversial. Because enteric neurons take up 5-HT (Gershon and Altman, 1971; Gershon and Sherman, 1982; Erde et al., 1985; Wade et al., 1996; Chen et al., 1998), 5-HT-containing neurons have been called " 5 -HT accumulating," to suggest that their 5-HT is EC cell derived (Meedeniya et al., 1998). Mucosal 5-HT, however, does not normally reach myenteric ganglia (Bülbring and Lin, 1958; Gershon and Tamir, 1981). Stimulated enteric neurons nevertheless release 5-HT (Gershon and Tamir, 1981); moreover, 5-HT receptor blocking anti-idiotypic antibodies (Wade et al., 1994) and acute 5-HT depletion (Takaki et al., 1985) abolish putatively serotonergic slow EPSPs. Criteria needed to establish 5-HT as an enteric neurotransmitter (Gershon, 2009) 
were finally completed by the discovery that enteric neurons express TPH2 (Neal et al., 2009).

Our observations that total GI transit time, small bowel transit, and colonic motility are abnormally slow in $\mathrm{TPH} 2 \mathrm{KO}$ mice are consistent with previous suggestions that 5-HT mediates propagating contractile complexes (Neal et al., 2009) and slow (Erde et al., 1985; Takaki et al., 1985; Wade et al., 1994) and fast (Galligan et al., 2000) excitatory synaptic responses. They are also consistent with suggestions that constitutive inhibition of circular muscle and migrating motor complexes depend on myenteric serotonergic interneurons (Dickson et al., 2010; Heredia et al., 2010) rather than mucosal 5-HT (Keating and Spencer, 2010). The paradoxical acceleration of gastric emptying in TPH2-deficient mice is consistent with previous reports that 5-HT participates in vagal inhibition of the stomach (Bülbring and Gershon, 1967b), 5- $\mathrm{HT}_{1 \mathrm{P}}$ antagonism accelerates gastric emptying (Mawe et al., 1989), and 5-HT functions in vagal gastric accommodation reflexes (Reisoli et al., 2010). 5- $\mathrm{HT}_{3}$ agonists (Spencer et al., 1998) and the 5-HT releasing agent fenfluramine (Serio et al., 2003; Soll et al., 2010) also retard gastric emptying. Neuronal 5-HT may thus excite gastric inhibitory neurons, which delay gastric emptying.

It is surprising that motility is not abnormal in TPH1KO mice because increased intraluminal pressure and nutrients release 5-HT from EC cells, which initiates peristaltic and secretory reflexes (Bülbring and Crema, 1959a; Cooke et al., 1997; Pan and Gershon, 2000; Bertrand, 2004; Patel et al., 2007; Spiller, 2007). Conceivably, the peristaltic reflex does not contribute significantly to constitutive motility but is instead manifested only in distension- or stressinduced behaviors, such as giant migrating contractions or "power propulsion" (Sarna, 2007; Wood, 2008, 2010). Although the alternative possibility that another mediator may, in TPH1KO mice, assume the role normally played by $5-\mathrm{HT}$ cannot be excluded, depletion of mucosal 5-HT with reserpine (Bülbring and Crema, 1959b) or tryptophan depletion also fails to abolish peristaltic reflexes (Boullin, 1964).

The current studies of TPH2-deficient mice suggest that enteric serotonergic neurons play a physiologically important role in enteric neuronal development/survival. That 5-HT might be an enteric neuronal growth factor was first suggested by observations that $5-\mathrm{HT}_{2 \mathrm{~B}}$ receptors are neuronal, developmentally regulated, and promote development of neurons from isolated ENCDCs (Fiorica-Howells et al., 2000). Subsequently, 5- $\mathrm{HT}_{4}$ receptors were demonstrated to be neuroprotective and to promote the development of new neurons from adult stem cells (Liu et al., 2009). Because enteric neurons are born asynchronously (Pham
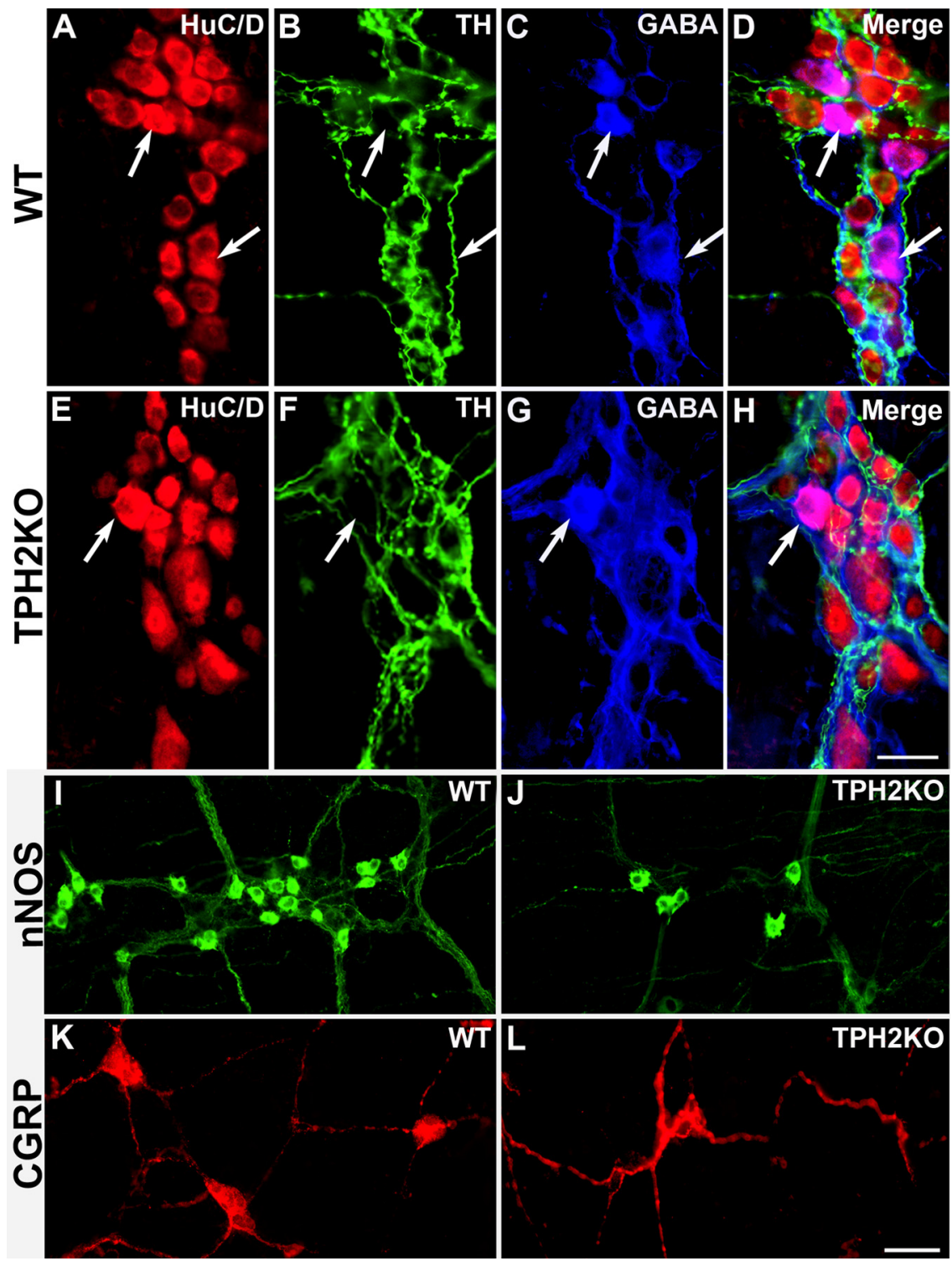

Figure 7. Deletion of TPH2 reduces the numbers of GABAergic, nitrergic, and CGRP-expressing neurons but does not affect the density of sympathetic terminal axons in the ENS; the immunoreactivities of TH and GABA are not coincident. The immunoreactivities of HuC/D (total neurons), TH, and GABA were demonstrated simultaneously in LMMP preparations of WT (A-D) and TPH2KO mouse; TH. G, TPH2KO mouse; GABA. $\boldsymbol{H}$, TPH2KO mouse; merged image. Whole-mount preparations were also used to demonstrate the immunoreactivities of nNOS in the myenteric $(\boldsymbol{I}, \boldsymbol{J})$ and $(G R P$ in the submucosal plexus $(\boldsymbol{K}, \boldsymbol{L})$. $\boldsymbol{I}$, WT mouse; $\mathrm{nNOS}$ J, TPH2KO mouse; nNOS. $K$, WT mouse; CGRP. L, TPH2KO mouse; CGRP. Note that the density of TH-immunoreactive sympathetic terminals in the myenteric plexus is similar in WT $(\boldsymbol{B})$ and TPH2KO $(\boldsymbol{F})$ mice. Scale bars: $\boldsymbol{A}-\boldsymbol{H}, 25 \mu \mathrm{m} ; \boldsymbol{I}-\boldsymbol{L}, 50 \mu \mathrm{m}$.

et al., 1991) and serotonergic neurons are among the first to arise (Pham et al., 1991; Blaugrund et al., 1996; Chalazonitis et al., 2008), it follows that serotonergic neurons coexist with dividing ENCDCs, some of which receive synapses (Gershon et al., 1981). It is thus plausible that serotonergic input influences the fate of ENCDCs; these precursors express SERT and 15 subtypes of 5-HT receptor.

Dopaminergic, GABAergic, and CGRP-expressing neurons are among the last enteric neurons to be born (Pham et al., 1991; Li et al., 2004; Chalazonitis et al., 2008); birthdays of enteric serotonergic neurons conclude (E15) before birthdays of these neurons begin. The development/survival of dopaminergic and other late-born enteric neurons could thus be influenced by serotonergic neuronal activity. In fact, the ENS of mice lacking 
A
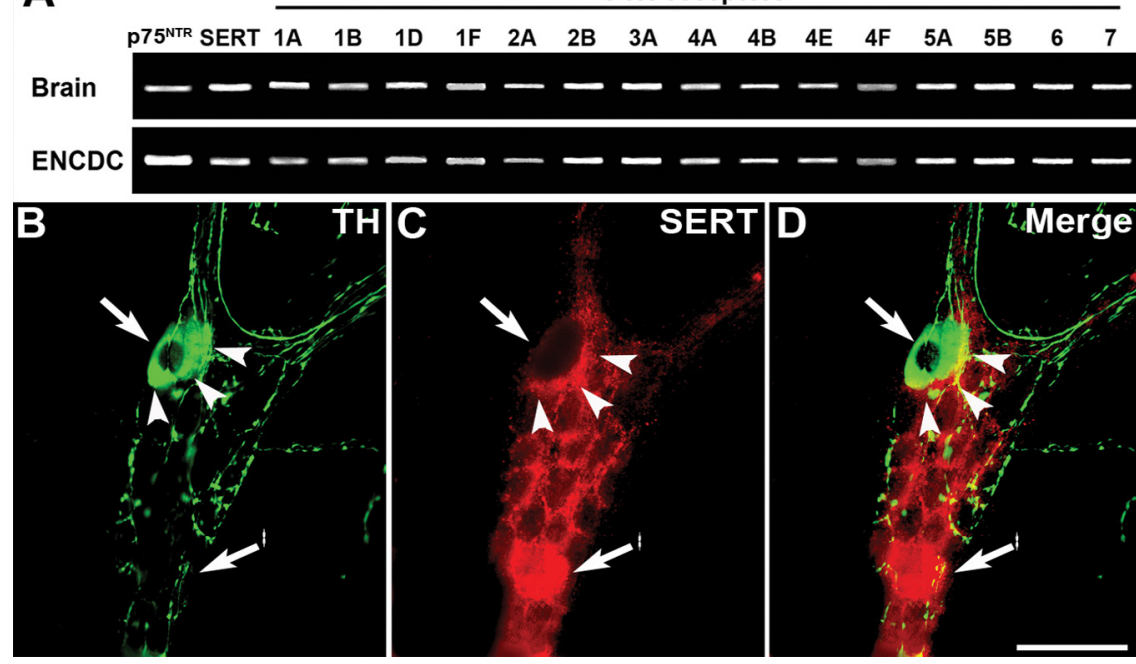

Figure 8. ENCDC precursor late-born enteric neurons express many subtypes of 5-HT receptor and SERT; myenteric dopaminergic neurons do not express SERT but are surrounded by a ring of SERT-immunoreactive (putatively serotonergic) terminal axons. $\boldsymbol{A}$, Immunoselection with antibodies to $\mathrm{p} 75^{\mathrm{NTR}}$ was used to isolate from the fetal intestine at E16. RT-PCR was used to determine whether these cells express transcripts encoding 15 subtypes, encompassing each of the families of 5 -HT receptor. The brain was investigated as a positive control. In addition to p75NTR, both brain and ENCDCs contained transcripts encoding SERT, $5-\mathrm{HT}_{1 \mathrm{~A}^{\prime}}$ $5-\mathrm{HT}_{1 B}, 15-\mathrm{HT}_{10}, 5-\mathrm{HT}_{1 \mathrm{~F}}, 5-\mathrm{HT}_{2 \mathrm{~A}}, 5-\mathrm{HT}_{2 \mathrm{~B}}, 5-\mathrm{HT}_{3 \mathrm{~A}}, 5-\mathrm{HT}_{4 \mathrm{~A}}, 5-\mathrm{HT}_{4 \mathrm{~B}}, 5-\mathrm{HT}_{4 \mathrm{E}}, 5-\mathrm{HT}_{4 \mathrm{~F}}, 5-\mathrm{HT}_{5 \mathrm{~A}}, 5-\mathrm{HT}_{5 \mathrm{~B}}, 5-\mathrm{HT}_{6}$, and $5-\mathrm{HT}_{7}$ receptors. $\boldsymbol{B}-\boldsymbol{D}$, TH and SERT immunoreactivities were demonstrated simultaneously in whole mounts of LMMP from adult mouse ileum. The location, in each panel of a TH-immunoreactive nerve cell body, is shown by an arrow, the location of the ring of SERTimmunoreactive terminal axons by arrowheads, and a SERT-immunoreactive nerve cell body by an arrow with an asterisk. $\boldsymbol{B}$, TH immunoreactivity. C, SERT immunoreactivity. D, Merged image. Scale bar, $50 \mu \mathrm{m}$.

TPH2 contained fewer total, dopaminergic, GABAergic, CGRPexpressing, and nitrergic neurons than the ENS of WT mice, which did not differ significantly from those of TPH1KO animals. Because dopaminergic neuronal numbers in TPH2KO mice were not significantly different from those in TPH1/2dKO animals, neuronal and not mucosal 5-HT must be the pool that affects the development/ survival of enteric neurons. The deficits in dopaminergic and GABAergic neurons in mice lacking TPH2 were proportionally greater than that in total neurons, suggesting that the development/ survival of some classes of late-born neurons is particularly 5-HT dependent. The abundance of transcripts encoding TH and DAT, like that of TH-immunoreactive neurons, was also lower in TPH2deficient mice than in WT littermates, and again, neither TH nor DAT transcripts were reduced in TPH1KO animals.

Enteric dopaminergic neurons slow gastrointestinal motility; intestinal transit is accelerated in mice that lack neuronal dopamine receptors $\left(\mathrm{D}_{2}\right.$ or both $\mathrm{D}_{2}$ and $\left.\mathrm{D}_{3}\right)$ (Li et al., 2006), and DAT deletion potentiates dopaminergic inhibition of colonic transit and muscle contraction (Walker et al., 2000). Because enteric dopaminergic neurons are thus a brake on intestinal motility, their abnormality in mice lacking TPH2 does not explain the slow transit of these animals. Slow intestinal transit thus occurs in TPH2-deficient mice despite and not because of their dopaminergic defect. DAT transcription is upregulated in TPH1KO mice. Conceivably, DAT upregulation compensates for the absence of mucosal 5-HT. By diminishing the efficacy of the DAT brake, DAT upregulation in TPH1KO mice might ameliorate the absence of 5-HT-initiated mucosal reflexes.

Experiments in which 5-HT was applied to isolated ENCDCs confirmed that 5-HT promotes development/survival of enteric neurons. In ENCDC cultures, 5-HT increased the concentration of DA, dopaminergic neurite extension, and the numbers of both total and TH-immunoreactive neurons. 5-HT, however, did not alter the dopaminergic/total neuron ratio. In part, this is because, as discussed above, the effects of 5-HT on development/survival are not restricted to dopaminergic neurons. Still, in TPH2KO and TPH1/ $2 \mathrm{dKO}$ mice, a greater deficiency occurs in dopaminergic than in total neurons. This differential effect is consistent with the proposed role of 5-HT to regulate development only of enteric neurons generated after serotonergic neurons have been born. The normal development of 5-HTindependent early-developing neurons in TPH2KO mice would reduce the magnitude of the deficit in total neurons and lead to the disproportionate defects in dopaminergic, GABAergic, CGRPexpressing, and those nitrergic neurons that develop after their serotonergic counterparts. In contrast, when $5-\mathrm{HT}$ is added to ENCDCs isolated at E16, earlydeveloping neurons have already been born and are not generated from ENCDCs proliferating at that time. All neurons generated from ENCDCs at E16 are thus post-serotonergic, and many, including the myenteric dopaminergic, GABAergic, and submucosal CGRPexpressing subsets, are 5-HT responsive. 5-HT, therefore, may not cause ENCDCs to acquire their definitive phenotype (e.g., become dopaminergic) but may be necessary for them to develop and/or survive.

SERTKO mice were investigated as a gain-of-function model to investigate serotonergic effects on enteric dopaminergic neurons. Although SERT deletion did not affect the DA concentration, it increased the ileal concentration of HVA and the total content of DA and its metabolites. It is not surprising that the level of DA does not change in SERTKO mice because regulatory mechanisms modulate the rate of catecholamine biosynthesis in neurons, preventing a change in transmitter content as a result of neuronal activity (Molinoff and Axelrod, 1971); however, the increase in DA metabolites suggests that, by enhancing the action of 5-HT, SERTKO increases dopaminergic neuronal activity. The developmental serotonergic influence on dopaminergic neuronal development/survival may thus be retained in the adult ENS as a serotonergic innervation of dopaminergic neurons, which is also suggested by the ring of SERT-immunoreactive terminal axons found to surround myenteric dopaminergic neurons. The deletion of SERT affected 5-HIAA differently from HVA. The concentration of 5-HIAA and the sum of the concentrations of 5-HT and 5-HIAA were lower in the SERTKO than WT colon. Similar reductions in 5-HT also occur in the brains of SERTKO mice (Kim et al., 2005). This observation suggests that feedback control may reduce serotonergic neuronal activity in SERTKO mice. Feedback may also be evident in SERT expression. Enteric serotonergic neurons express SERT (Gershon and Sherman, 1982; Erde et al., 1985; Wade et al., 1996; Chen et al., 1998), and transcription of SERT was significantly decreased in both ileum and colon of TPH1/2dKO mice, which lack 5-HT. Because SERT is important in terminating the action of 5-HT, it is reasonable that feedback downregulation of SERT would accompany the absence of serotonergic signaling. 


\section{References}

Bertrand PP (2004) Real-time detection of serotonin release from enterochromaffin cells of the guinea-pig ileum. Neurogastroenterol Motil 16:511-514.

Bertrand PP, Bertrand RL (2010) Serotonin release and uptake in the gastrointestinal tract. Auton Neurosci 153:47-57.

Bertrand PP, Hu X, Mach J, Bertrand RL (2008) Serotonin (5-HT) release and uptake measured by real-time electrochemical techniques in the rat ileum. Am J Physiol Gastrointest Liver Physiol 295:G1228-G1236.

Bian X, Patel B, Dai X, Galligan JJ, Swain G (2007) High mucosal serotonin availability in neonatal guinea pig ileum is associated with low serotonin transporter expression. Gastroenterology 132:2438-2447.

Blaugrund E, Pham TD, Tennyson VM, Lo L, Sommer L, Anderson DJ, Gershon MD (1996) Distinct subpopulations of enteric neuronal progenitors defined by time of development, sympathoadrenal lineage markers, and Mash-1-dependence. Development 122:309-320.

Boullin DJ (1964) Observations on the significance of 5-hydroxytryptamine in relation to the peristaltic reflex of the rat. Br J Pharmacol 23:14-33.

Bülbring E, Crema A (1959a) The release of 5-hydroxytryptamine in relation to pressure exerted on the intestinal mucosa. J Physiol 146:18-28.

Bülbring E, Crema A (1959b) The action of 5-hydroxytryptamine, 5 -hydroxytryptophan and reserpine on intestinal peristalsis in anaesthetized guinea-pigs. J Physiol 146:29-53.

Bülbring E, Gershon MD (1967a) 5-hydroxytryptamine participation in the vagal inhibitory innervation of the stomach. J Physiol 192:823-846.

Bülbring E, Gershon MD (1967b) Serotonin participation in the vagal inhibitory pathway to the stomach. Adv Pharmacol 6:323-333.

Bülbring E, Lin RC (1958) The effect of intraluminal application of 5-hydroxytryptamine and 5-hydroxytryptophan on peristalsis, the local production of 5-hydroxytryptamine and its release in relation to intraluminal pressure and propulsive activity. J Physiol 140:381-407.

Chalazonitis A, Rothman TP, Chen J, Gershon MD (1998) Age-dependent differences in the effects of GDNF and NT-3 on the development of neurons and glia from neural crest-derived precursors immunoselected from the fetal rat gut: expression of GFRa-1 in vitro and in vivo. Dev Biol 204:385-406.

Chalazonitis A, D'Autréaux F, Guha U, Pham TD, Faure C, Chen JJ, Roman D, Kan L, Rothman TP, Kessler JA, Gershon MD (2004) Bone morphogenetic protein-2 and -4 limit the number of enteric neurons but promote development of a TrkC-expressing neurotrophin-3-dependent subset. J Neurosci 24:4266-4282.

Chalazonitis A, Pham TD, Li Z, Roman D, Guha U, Gomes W, Kan L, Kessler JA, Gershon MD (2008) Bone morphogenetic protein regulation of enteric neuronal phenotypic diversity: relationship to timing of cell cycle exit. J Comp Neurol 509:474-492.

Chen JJ, Wan S, Gershon MD (2004) Expression of two isoforms of tryptophan hydroxylase (TPH1 and TPH2) in human and mouse gut. Gastroenterology 126:A411.

Chen JX, Pan H, Rothman TP, Wade PR, Gershon MD (1998) Guinea pig 5-HT transporter: cloning, expression, distribution and function in intestinal sensory reception. Am J Physiol 275:G433-G448.

Coates MD, Johnson AC, Greenwood-Van Meerveld B, Mawe GM (2006) Effects of serotonin transporter inhibition on gastrointestinal motility and colonic sensitivity in the mouse. Neurogastroenterol Motil 18:464-471.

Cooke HJ, Sidhu M, Wang YZ (1997) 5-HT activates neural reflexes regulating secretion in the guinea-pig colon. Neurogastroenterol Motil 9:181-186.

Côté F, Thévenot E, Fligny C, Fromes Y, Darmon M, Ripoche MA, Bayard E, Hanoun N, Saurini F, Lechat P, Dandolo L, Hamon M, Mallet J, Vodjdani G (2003) Disruption of the nonneuronal tph1 gene demonstrates the importance of peripheral serotonin in cardiac function. Proc Natl Acad Sci U S A 100:13525-13530.

Davies PA, Pistis M, Hanna MC, Peters JA, Lambert JJ, Hales TG, Kirkness EF (1999) The $5-\mathrm{HT}_{3 \mathrm{~B}}$ subunit is a major determinant of serotonin-receptor function. Nature 397:359-363.

Dickson EJ, Heredia DJ, Smith TK (2010) Critical role of 5-HT1A, 5-HT3, and 5-HT7 receptor subtypes in the initiation, generation, and propagation of the murine colonic migrating motor complex. Am J Physiol Gastrointest Liver Physiol 299:G144-G157.

Erde SM, Sherman D, Gershon MD (1985) Morphology and serotonergic innervation of physiologically identified cells of the guinea pig's myenteric plexus. J Neurosci 5:617-633.

Fiorica-Howells E, Maroteaux L, Gershon MD (2000) Serotonin and the $5-\mathrm{HT}(2 \mathrm{~B})$ receptor in the development of enteric neurons. J Neurosci 20:294-305.

Furness J (2006) The enteric nervous system, Ed 2. Malden, MA: Blackwell.

Galligan JJ, LePard KJ, Schneider DA, Zhou X (2000) Multiple mechanisms of fast excitatory synaptic transmission in the enteric nervous system. J Auton Nerv Syst 81:97-103.

Gershon MD (2009) Enteric serotonergic neurons . . . finally! J Physiol 587:507.

Gershon MD, Altman RF (1971) An analysis of the uptake of 5-hdyroxytryptamine by the myenteric plexus of the small intestine of the guinea pig. J Pharmacol Exp Ther 179:29-41.

Gershon MD, Sherman D (1982) Selective demonstration of serotonergic neurons and terminals in electron micrographs: loading with 5,7dihydroxytryptamine and fixation with $\mathrm{NaMnO}_{4}$. J Histochem Cytochem 30:769-773.

Gershon MD, Tack J (2007) The serotonin signaling system: from basic understanding to drug development for functional GI disorders. Gastroenterology 132:397-414.

Gershon MD, Tamir H (1981) Release of endogenous 5-hydroxytryptamine from resting and stimulated enteric neurons. Neuroscience 6:2277-2286.

Gershon MD, Sherman D, Gintzler AR (1981) An ultrastructural analysis of the developing enteric nervous system of the guinea pig small intestine. J Neurocytol 10:271-296.

Gershon MD, Ratcliffe E, M. (2006) Development of the enteric nervous system. In: Physiology of the gastrointestinal tract, Ed 4 (Johnson LR, Barrett KE, Ghishan FK, Mechant JL, Said HM, Wood JD, eds), pp $499-$ 521. Burlington, MA: Elsevier Academic.

Ghia JE, Li N, Wang H, Collins M, Deng Y, El-Sharkawy RT, Côté F, Mallet J, Khan WI (2009) Serotonin has a key role in pathogenesis of experimental colitis. Gastroenterology 137:1649-1660.

Gutknecht L, Kriegebaum C, Waider J, Schmitt A, Lesch KP (2009) Spatiotemporal expression of tryptophan hydroxylase isoforms in murine and human brain: convergent data from Tph2 knockout mice. Eur Neuropsychopharmacol 19:266-282.

Hao MM, Young HM (2009) Development of enteric neuron diversity. J Cell Mol Med 13:1193-1210.

Heredia DJ, Dickson EJ, Bayguinov PO, Hennig GW, Smith TK (2010) Colonic elongation inhibits pellet propulsion and migrating motor complexes in the murine large bowel. J Physiol 588:2919-2934.

Huber LJ, Chao MV (1995) Mesenchymal and neuronal cell expression of the p75 neurotrophin gene occur by different mechanisms. Dev Biol 167:227-238.

Keating DJ, Spencer NJ (2010) Release of 5-hydroxytryptamine from the mucosa is not required for the generation or propagation of colonic migrating motor complexes. Gastroenterology 138:659-670.

Kim DK, Tolliver TJ, Huang SJ, Martin BJ, Andrews AM, Wichems C, Holmes A, Lesch KP, Murphy DL (2005) Altered serotonin synthesis, turnover and dynamic regulation in multiple brain regions of mice lacking the serotonin transporter. Neuropharmacology 49:798-810.

Kimball ES, Palmer JM, D’Andrea MR, Hornby PJ, Wade PR (2005) Acute colitis induction by oil of mustard results in later development of an IBS-like accelerated upper GI transit in mice. Am J Physiol Gastrointest Liver Physiol 288:G1266-G1273.

Laranjeira C, Pachnis V (2009) Enteric nervous system development: recent progress and future challenges. Auton Neurosci 151:61-69.

Le Douarin NM, Teillet MA (1973) The migration of neural crest cells to the wall of the digestive tract in avian embryo. J Embryol Exp Morphol 30:31-48.

Li ZS, Pham TD, Tamir H, Chen JJ, Gershon MD (2004) Enteric dopaminergic neurons: definition, developmental lineage, and effects of extrinsic denervation. J Neurosci 24:1330-1339.

Li ZS, Schmauss C, Cuenca A, Ratcliffe E, Gershon MD (2006) Physiological modulation of intestinal motility by enteric dopaminergic neurons and the $\mathrm{D}_{2}$ receptor: analysis of dopamine receptor expression, location, development, and function in wild-type and knock-out mice. J Neurosci 26:2798-2807.

Liu MT, Rayport S, Jiang Y, Murphy DL, Gershon MD (2002) Expression and function of 5-HT3 receptors in the enteric neurons of mice lacking 
the serotonin transporter. Am J Physiol Gastrointest Liver Physiol 283:G1398-G1411.

Liu MT, Kuan YH, Wang J, Hen R, Gershon MD (2009) 5-HT4 receptormediated neuroprotection and neurogenesis in the enteric nervous system of adult mice. J Neurosci 29:9683-9699.

Mawe GM, Branchek T, Gershon MD (1989) Blockade of 5-HT-mediated enteric slow EPSPs by BRL 24924: gastrokinetic effects. Am J Physiol Gastrointest Liver Physiol 257:G386-G396.

Meedeniya AC, Brookes SJ, Hennig GW, Costa M (1998) The projections of 5-hydroxytryptamine-accumulating neurones in the myenteric plexus of the small intestine of the guinea-pig. Cell Tissue Res 291:375-384.

Miller MS, Galligan JJ, Burks TF (1981) Accurate measurement of intestinal transit in the rat. J Pharmacol Methods 6:211-217.

Molinoff PB, Axelrod J (1971) Biochemistry of catecholamines. Annu Rev Biochem 40:465-500.

Monro RL, Bertrand PP, Bornstein JC (2002) ATP and 5-HT are the principal neurotransmitters in the descending excitatory reflex pathway of the guinea-pig ileum. Neurogastroenterol Motil 14:255-264.

Neal KB, Parry LJ, Bornstein JC (2009) Strain-specific genetics, anatomy and function of enteric neural serotonergic pathways in inbred mice. J Physiol 587:567-586.

Noguchi T, Nishino M, Kido R (1973) Tryptophan 5-hydroxylase in rat intestine. Biochem J 131:375-380.

Pan H, Gershon MD (2000) Activation of intrinsic afferent pathways in submucosal ganglia of the guinea pig small intestine. J Neurosci 20:3295-3309.

Patel BA, Bian X, Quaiserová-Mocko V, Galligan JJ, Swain GM (2007) In vitro continuous amperometric monitoring of 5-hydroxytryptamine release from enterochromaffin cells of the guinea pig ileum. Analyst 132:41-47.

Pham TD, Gershon MD, Rothman TP (1991) Time of origin of neurons in the murine enteric nervous system. J Comp Neurol 314:789-798.

Reisoli E, De Lucchini S, Nardi I, Ori M (2010) Serotonin 2B receptor signaling is required for craniofacial morphogenesis and jaw joint formation in Xenopus. Development 137:2927-2937.

Sarna SK (2007) Enteric descending and afferent neural signaling stimulated by giant migrating contractions: essential contributing factors to visceral pain. Am J Physiol Gastrointest Liver Physiol 292:G572-G581.

Savelieva KV, Zhao S, Pogorelov VM, Rajan I, Yang Q, Cullinan E, Lanthorn TH (2008) Genetic disruption of both tryptophan hydroxylase genes dramatically reduces serotonin and affects behavior in models sensitive to antidepressants. PLoS One 3:e3301.

Serio R, Alessandro M, Zizzo MG, Tamburello MP, Mulè F (2003) Neurotransmitters involved in the fast inhibitory junction potentials in mouse distal colon. Eur J Pharmacol 460:183-190.
Soll C, Jang JH, Riener MO, Moritz W, Wild PJ, Graf R, Clavien PA (2010) Serotonin promotes tumor growth in human hepatocellular cancer. Hepatology 51:1244-1254.

Spencer NJ, Bywater RA, Holman ME, Taylor GS (1998) Inhibitory neurotransmission in the circular muscle layer of mouse colon. J Auton Nerv Syst 70:10-14.

Spiller R (2007) Recent advances in understanding the role of serotonin in gastrointestinal motility in functional bowel disorders: alterations in 5-HT signalling and metabolism in human disease. Neurogastroenterol Motil 19 [Suppl 2]:25-31.

Spiller R (2008) Serotonin and GI clinical disorders. Neuropharmacology 55:1072-1080.

Takaki M, Mawe GM, Barasch JM, Gershon MD (1985) Physiological responses of guinea-pig myenteric neurons secondary to the release of endogenous serotonin by tryptamine. Neuroscience 16:223-240.

Wade PR, Tamir H, Kirchgessner AL, Gershon MD (1994) Analysis of the role of 5-HT in the enteric nervous system using anti-idiotypic antibodies to 5-HT receptors. Am J Physiol 266:G403-G416.

Wade PR, Chen J, Jaffe B, Kassem IS, Blakely RD, Gershon MD (1996) Localization and function of a 5-HT transporter in crypt epithelia of the gastrointestinal tract. J Neurosci 16:2352-2364.

Walker JK, Gainetdinov RR, Mangel AW, Caron MG, Shetzline MA (2000) Mice lacking the dopamine transporter display altered regulation of distal colonic motility. Am J Physiol Gastrointest Liver Physiol 279:G311-G318.

Walther DJ, Peter JU, Bashammakh S, Hörtnagl H, Voits M, Fink H, Bader M (2003) Synthesis of serotonin by a second tryptophan hydroxylase isoform. Science 299:76.

Wood JD (2008) Enteric nervous system: reflexes, pattern generators and motility. Curr Opin Gastroenterol 24:149-158.

Wood JD (2010) Enteric nervous system: sensory physiology, diarrhea and constipation. Curr Opin Gastroenterol 26:102-108.

Yadav VK, Ryu JH, Suda N, Tanaka KF, Gingrich JA, Schütz G, Glorieux FH, Chiang CY, Zajac JD, Insogna KL, Mann JJ, Hen R, Ducy P, Karsenty G (2008) Lrp5 controls bone formation by inhibiting serotonin synthesis in the duodenum. Cell 135:825-837.

Yntema CL, Hammond WS (1954) The origin of intrinsic ganglia of trunk viscera from vagal neural crest in the chick embryo. J Comp Neurol 101:515-541.

Yntema CL, Hammond WS (1955) Experiments on the origin and development of the sacral autonomic nerves in the chick embryo. J Exp Zool 129:375-414

Ziller C, Dupin E, Brazeau P, Paulin D, Le Douarin NM (1983) Early segregation of a neuronal precursor cell line in the neural crest as revealed by culture in a chemically defined medium. Cell 32:627-638. 